Article

\title{
Ruthenafuran Complexes Supported by the Bipyridine-Bis(diphenylphosphino)methane Ligand Set: Synthesis and Cytotoxicity Studies
}

\author{
Chi-Fung Yeung ${ }^{1,2,+}$, Sik-Him Tang ${ }^{1,+}{ }^{,}$, Zhe Yang ${ }^{1,+}$, Tsun-Yin Li ${ }^{1}$, Ka-Kit Li ${ }^{1}$, Yuen-Man Chan ${ }^{1}$, Hau-Lam Shek ${ }^{1}$, \\ Kai-Wa Io ${ }^{1}$, King-Ting Tam ${ }^{1}$, Shek-Man Yiu ${ }^{1}$, Man-Kit Tse ${ }^{1}$ and Chun-Yuen Wong ${ }^{1,2, * \mathbb{D}}$
}

check for updates

Citation: Yeung, C.-F.; Tang, S.-H.; Yang, Z.; Li, T.-Y.; Li, K.-K.; Chan, Y.-M.; Shek, H.-L.; Io, K.-W.; Tam, K.-T.; Yiu, S.-M.; et al. Ruthenafuran Complexes Supported by the Bipyridine-

Bis(diphenylphosphino)methane

Ligand Set: Synthesis and

Cytotoxicity Studies. Molecules 2022,

27, 1709. https://doi.org/

10.3390/molecules27051709

Academic Editors: Sandra Bolaño and Maria Talavera

Received: 4 February 2022

Accepted: 3 March 2022

Published: 5 March 2022

Publisher's Note: MDPI stays neutral with regard to jurisdictional claims in published maps and institutional affiliations.

Copyright: (C) 2022 by the authors. Licensee MDPI, Basel, Switzerland. This article is an open access article distributed under the terms and conditions of the Creative Commons Attribution (CC BY) license (https:// creativecommons.org/licenses/by/ $4.0 /)$.
1 Department of Chemistry, City University of Hong Kong, Tat Chee Avenue, Kowloon, Hong Kong; chifyeung3-c@my.cityu.edu.hk (C.-F.Y.); sikhtang3-c@my.cityu.edu.hk (S.-H.T.); zyang36-c@my.cityu.edu.hk (Z.Y.); tsunyinli7-c@my.cityu.edu.hk (T.-Y.L.); kakitli8-c@my.cityu.edu.hk (K.-K.L.); symchan@cityu.edu.hk (Y.-M.C.); hlshek5-c@my.cityu.edu.hk (H.-L.S.); kaiio2-c@my.cityu.edu.hk (K.-W.I.); kingttam3-c@my.cityu.edu.hk (K.-T.T.); kensmyiu@cityu.edu.hk (S.-M.Y.); manktse@cityu.edu.hk (M.-K.T.)

2 State Key Laboratory of Terahertz and Millimeter Waves, City University of Hong Kong, Tat Chee Avenue, Kowloon, Hong Kong

* Correspondence: acywong@cityu.edu.hk; Tel.: +852-3442-6831

+ These authors contributed equally to this work.

\begin{abstract}
Mononuclear and dinuclear $\mathrm{Ru}(\mathrm{II})$ complexes cis-[Ru( $\left.\left.\kappa^{2}-\mathrm{dppm}\right)(\mathrm{bpy}) \mathrm{Cl}_{2}\right](\mathbf{1})$, cis- $\left[\mathrm{Ru}\left(\kappa^{2}\right.\right.$ dppe $)($ bpy $\left.) \mathrm{Cl}_{2}\right](2)$ and $\left[\mathrm{Ru}_{2}(\mathrm{bpy})_{2}(\mu \text {-dpam })_{2}(\mu-\mathrm{Cl})_{2}\right](\mathrm{Cl})_{2}\left([3](\mathrm{Cl})_{2}\right)$ were prepared from the reactions between $\operatorname{cis}(\mathrm{Cl})$, cis $(\mathrm{S})-\left[\mathrm{Ru}(\mathrm{bpy})(\mathrm{dmso}-\mathrm{S})_{2} \mathrm{Cl}_{2}\right]$ and diphosphine/diarsine ligands (bpy $=2,2^{\prime}$ bipyridine; $\mathrm{dppm}=1,1$-bis(diphenylphosphino)methane; dppe = 1,2-bis(diphenylphosphino)ethane; dpam $=1,1$-bis(diphenylarsino)methane). While methoxy-substituted ruthenafuran $\left[\mathrm{Ru}(\mathrm{bpy})\left(\mathrm{\kappa}^{2}-\right.\right.$ dppe $\left.)\left(\mathrm{C}^{\wedge} \mathrm{O}\right)\right]^{+}\left([7]^{+} ; \mathrm{C}^{\wedge} \mathrm{O}=\right.$ anionic bidentate $[\mathrm{C}(\mathrm{OMe}) \mathrm{CHC}(\mathrm{Ph}) \mathrm{O}]^{-}$chelate $)$was obtained as the only product in the reaction between 2 and phenyl ynone $\mathrm{HC} \equiv \mathrm{C}(\mathrm{C}=\mathrm{O}) \mathrm{Ph}$ in $\mathrm{MeOH}$, replacing 2 with 1 led to the formation of both methoxy-substituted ruthenafuran $\left[\mathrm{Ru}(\mathrm{bpy})\left(\kappa^{2}-\mathrm{dppm}\right)\left(\mathrm{C}^{\wedge} \mathrm{O}\right)\right]^{+}$ $\left([4]^{+}\right)$and phosphonium-ring-fused bicyclic ruthenafuran $\left[\mathrm{Ru}(\mathrm{bpy})\left(\mathrm{P}^{\wedge} \mathrm{C}^{\wedge} \mathrm{O}\right) \mathrm{Cl}\right]^{+}\left([5]^{+} ; \mathrm{P}^{\wedge} \mathrm{C}^{\wedge} \mathrm{O}=\right.$ neutral tridentate $\left[(\mathrm{Ph})_{2} \mathrm{PCH}_{2} \mathrm{P}(\mathrm{Ph})_{2} \mathrm{CCHC}(\mathrm{Ph}) \mathrm{O}\right]$ chelate). All of these aforementioned metallafuran complexes were derived from $\mathrm{Ru}(\mathrm{II})$-vinylidene intermediates. The potential applications of these metallafuran complexes as anticancer agents were evaluated by in vitro cytotoxicity studies against cervical carcinoma (HeLa) cancer cell line. All the ruthenafuran complexes were found to be one order of magnitude more cytotoxic than cisplatin, which is one of the metal-based anticancer agents being widely used currently.
\end{abstract}

Keywords: ruthenium; alkyne activation; metallafuran; cytotoxicity

\section{Introduction}

Activation of alkynes by transition-metal complexes has recently gained increasing research interest in the field of organometallic chemistry [1-30]. Although the formation of metal-vinylidene species via alkyne-vinylidene rearrangement has been regarded as a key step in $\mathrm{Ru}(\mathrm{II})$-induced alkyne transformations, a number of our synthetic studies revealed that $\mathrm{Ru}(\mathrm{II})$ can also activate alkynes via "non-vinylidene" pathways [31,32]. With the aim to gain control on the modes of alkyne activation, we initiated research activities on probing and isolating intermediates and products from the reactions between functionalized alkynes and a variety of $\mathrm{Fe}(\mathrm{II}), \mathrm{Ru}(\mathrm{II})$ and Os(II) complexes [31-47]. In 2015, we reported the synthesis of metallafuran complexes in the form of $\left[\mathrm{M}(\mathrm{bpy})_{2}\left(\mathrm{C}^{\wedge} \mathrm{O}\right)\right]^{+}$from the reactions between cis-[M(bpy $\left.{ }_{2} \mathrm{Cl}_{2}\right](\mathrm{M}=\mathrm{Ru}, \mathrm{Os}$; bpy = 2,2'-bipyridine $)$ and ynone $\mathrm{HC} \equiv \mathrm{C}(\mathrm{C}=\mathrm{O}) \mathrm{Ph}$ in $\mathrm{MeOH}$ (Scheme $1 \mathrm{a} ; \mathrm{C}^{\wedge} \mathrm{O}$ represents an anionic bidentate $\left[\mathrm{C}(\mathrm{OMe}) \mathrm{CHC}(\mathrm{Ph}) \mathrm{O}^{-}{ }^{-}\right.$chelate, coordinating atoms in italics) [38]. Later in 2019, we discovered that reactions between 
cis-[M( $\left.\left.\kappa^{2}-\mathrm{dppm}\right)_{2} \mathrm{Cl}_{2}\right](\mathrm{M}=\mathrm{Ru}, \mathrm{Os} ; \mathrm{dppm}=1,1$-bis(diphenylphosphino)methane) and $\mathrm{HC} \equiv \mathrm{C}(\mathrm{C}=\mathrm{O}) \mathrm{Ph}$ in $\mathrm{MeOH}$ gave the phosphonium-ring-fused bicyclic metallafuran complexes in the form of $\left[\mathrm{M}\left(\mathrm{k}^{2}-\mathrm{dppm}\right)\left(\mathrm{P}^{\wedge} \mathrm{C}^{\wedge} \mathrm{O}\right) \mathrm{Cl}\right]^{+}$, but not $\left[\mathrm{M}\left(\mathrm{\kappa}^{2} \text {-dppm }\right)_{2}\left(\mathrm{C}^{\wedge} \mathrm{O}\right)\right]^{+}$(Scheme $1 \mathrm{~b}$; $\mathrm{P}^{\wedge} \mathrm{C}^{\wedge} \mathrm{O}$ represents a neutral tridentate $\left[(\mathrm{Ph})_{2} \mathrm{PCH}_{2} \mathrm{P}(\mathrm{Ph})_{2} \mathrm{CCHC}(\mathrm{Ph}) \mathrm{O}\right]$ chelate) [44]. This striking difference in reactivity suggested the participation of $\mathrm{dppm}$ in the reaction and led us to examine the reactions between $\mathrm{HC} \equiv \mathrm{C}(\mathrm{C}=\mathrm{O}) \mathrm{Ph}$ and $\left[\mathrm{Ru}\left(\kappa^{2}-\mathrm{L}^{\wedge} \mathrm{L}\right)(\mathrm{bpy}) \mathrm{Cl}_{2}\right]$, where $\mathrm{L}^{\wedge} \mathrm{L}$ represents bidentate phosphine or arsine ligands. We, in this paper, report (1) our attempts to synthesize various $\mathrm{Ru}(\mathrm{II})$ precursors in the form of $\left[\mathrm{Ru}\left(\mathrm{k}^{2}-\mathrm{L}^{\wedge} \mathrm{L}\right)(\mathrm{bpy}) \mathrm{Cl}_{2}\right]$, (2) their reactivity towards ynone $\mathrm{HC} \equiv \mathrm{C}(\mathrm{C}=\mathrm{O}) \mathrm{Ph}$, and (3) the cytotoxicity of the resultant complexes.

(a)<smiles>C#CC(=O)c1ccc(C(C)(C)C)cc1</smiles>

$M=\mathrm{Ru}^{\prime \prime}, \mathrm{Os}^{\prime \prime} \quad$ bpy $=2,2^{\prime}$-bipyridine<smiles>CC[PbH2+]</smiles>

(b) $\operatorname{cis}-\left[\mathrm{M}\left(\kappa^{2}-\mathrm{dppm}\right)_{2} \mathrm{Cl}_{2}\right]$
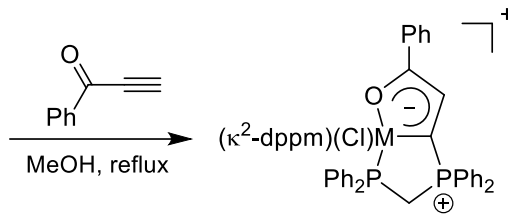

$M=\mathrm{Ru}^{\prime \prime}$, Os ${ }^{\prime \prime} \quad \mathrm{dppm}=1,1-\mathrm{bis}($ diphenylphosphino)methane

(c)<smiles></smiles>

Scheme 1. Formation of different metallafuran complexes from the reactions between phenyl ynone and (a) cis-[Ru/Os(bpy) $\left.{ }_{2} \mathrm{Cl}_{2}\right]$, (b) cis-[Ru/Os( $\left.\left.\kappa^{2}-\mathrm{dppm}\right)_{2} \mathrm{Cl}_{2}\right]$. (c) Mesomeric structures for the metallafuran moieties depicted in $(\mathbf{a}, \mathbf{b})$.

\section{Results and Discussion}

\subsection{Synthesis of Metal Precursors}

Attempts were made to prepare $\mathrm{Ru}(\mathrm{II})$ precursors in the form of $\left[\mathrm{Ru}\left(\kappa^{2}-\mathrm{L}^{\wedge} \mathrm{L}\right)(\mathrm{bpy}) \mathrm{Cl}_{2}\right]$ by reacting $\operatorname{cis}(\mathrm{Cl}), c i s(\mathrm{~S})-\left[\mathrm{Ru}(\mathrm{bpy})(\mathrm{dmso}-\mathrm{S})_{2} \mathrm{Cl}_{2}\right]$ with one equivalent of dppm, dppe (1,2bis(diphenylphosphino)ethane) or dpam (1,1-bis(diphenylarsino)methane) in alcoholic solvents (Scheme 2). While mononuclear $\mathrm{Ru}(\mathrm{II})$ precursors cis-[Ru( $\left.\left(\kappa^{2}-\mathrm{dppm}\right)(\mathrm{bpy}) \mathrm{Cl}_{2}\right]$ (1) and cis-[Ru( $\kappa^{2}$-dppe)(bpy) $\left.\mathrm{Cl}_{2}\right](2)$ were obtained as expected, the reaction involving dpam did not lead to any analogous mononuclear precursor but a dinuclear $\mathrm{Ru}$ (II) complex $\left[\mathrm{Ru}_{2}(\mathrm{bpy})_{2}(\mu \text {-dpam })_{2}(\mu-\mathrm{Cl})_{2}\right](\mathrm{Cl})_{2}\left([3](\mathrm{Cl})_{2}\right)$. The molecular structures for $\mathbf{1} \cdot \mathrm{CH}_{2} \mathrm{Cl}_{2}$ and [3] $(\mathrm{OTf})_{2} \cdot 2 \mathrm{CH}_{2} \mathrm{Cl}_{2}$ were determined by $\mathrm{X}$-ray crystallography (Figure 1 ). While the solidstate structure of [3](OTf $)_{2}$ revealed the existence of an inversion center at the center of the $\left[\mathrm{Ru}_{2} \mathrm{Cl}_{2}\right]$ rhomboid in $[3]^{2+}$, both the ${ }^{1} \mathrm{H}$ and ${ }^{13} \mathrm{C}$ spectra signified that $[3]^{2+}$ possessed a pseudo $\mathrm{D}_{2 \mathrm{~h}}$ symmetry in solution on the NMR time scale at room temperature (see Supplementary Materials). 


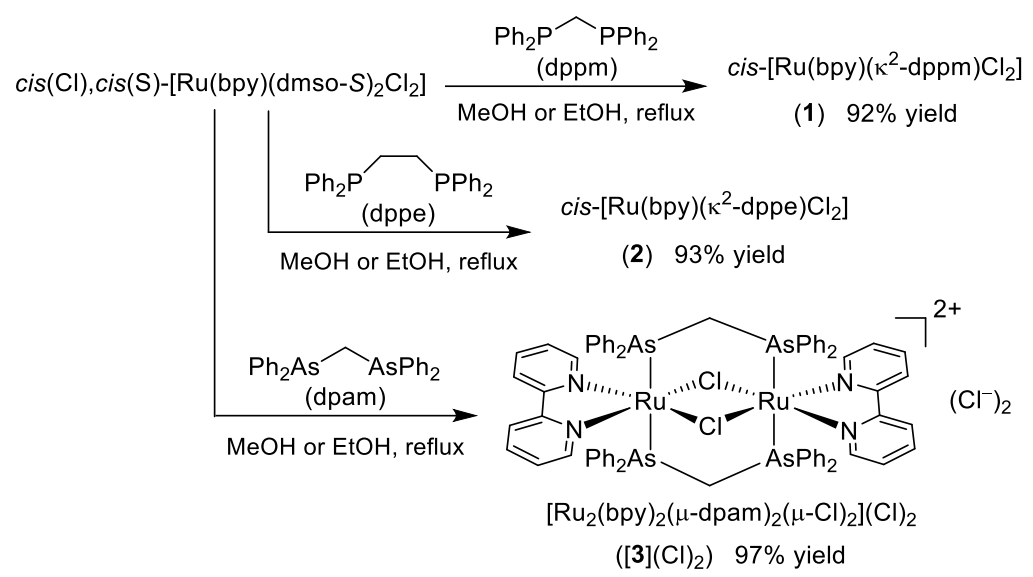

Scheme 2. Reactions between $\operatorname{cis}(\mathrm{Cl})$, $\operatorname{cis}(\mathrm{S})-\left[\mathrm{Ru}(\mathrm{bpy})(\mathrm{dmso}-\mathrm{S})_{2} \mathrm{Cl}_{2}\right]$ and bidentate phosphine/arsine ligands.

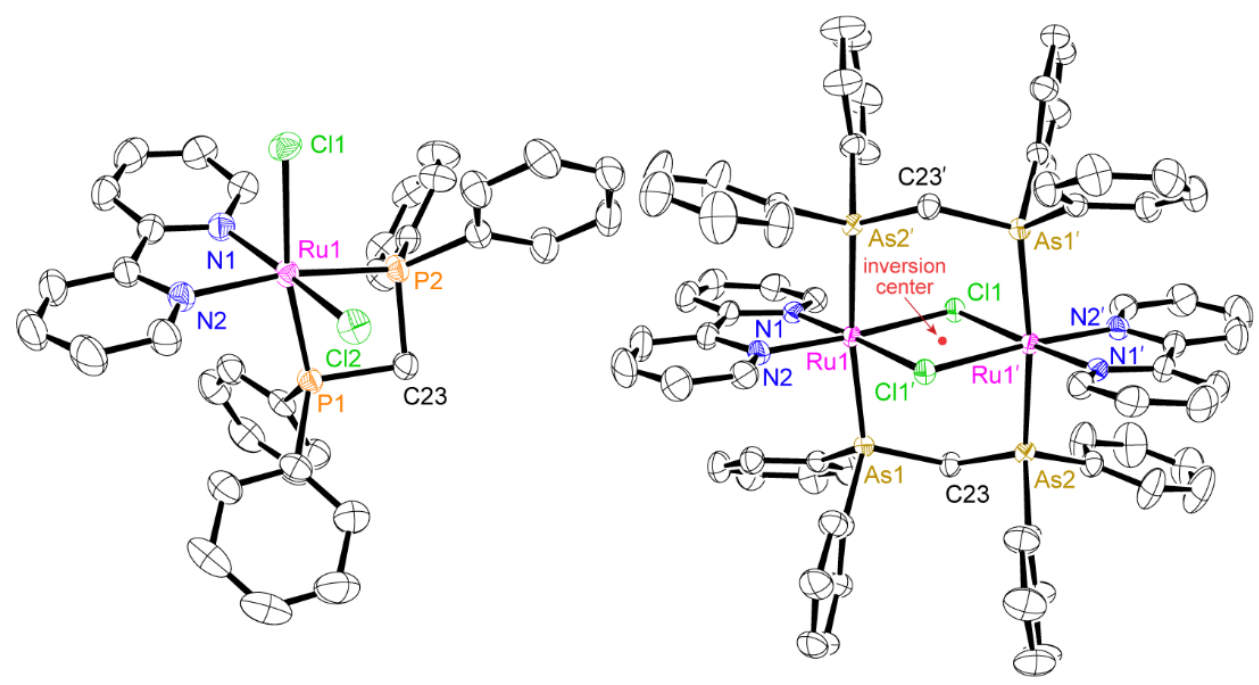

Figure 1. Perspective views of $\mathbf{1}$ (left) and $[3]^{2+}$ (right) as represented by $50 \%$ probability ellipsoids (hydrogen atoms are omitted for clarity). Selected bond lengths $(\AA)$ and angles $\left({ }^{\circ}\right)$ : 1: Ru1-Cl1 2.5059(6), Ru1-Cl2 2.4387(7), Ru1-N1 2.063(2), Ru1-N2 2.115(2), Ru1-P1 2.2654(7), Ru1-P2 2.2966(7), P1-Ru1-P 2 72.11(2), P1-C23-P2 93.25(11); [3] ${ }^{2+}:$ Ru1-Cl1 2.4418(8), Ru1-Cl1' 2.4383(8), Ru1-N1 2.031(3), Ru1-N2 2.046(3), Ru1-As1 2.4491(4), Ru1-As2 2.4570(4), Cl1-Ru1-Cl1' 83.00(3), Ru1-Cl1Ru1' 97.00(3), As1-C23-As2 118.16(17).

\subsection{Reactions between the Metal Precursors and Phenyl Ynone}

Reactions between phenyl ynone $\mathrm{HC} \equiv \mathrm{C}(\mathrm{C}=\mathrm{O}) \mathrm{Ph}$ and metal precursors 1, 2, and $[3](\mathrm{Cl})_{2}$ were investigated. While the ynone did not react with $[3](\mathrm{Cl})_{2}$, the reactions between $\mathrm{HC} \equiv \mathrm{C}(\mathrm{C}=\mathrm{O}) \mathrm{Ph}$ and metal precursors 1 and 2 led to different products, depending on the reaction conditions (Scheme 3a). A mixture of methoxy-substituted ruthenafuran $\left[\mathrm{Ru}(\mathrm{bpy})\left(\mathrm{\kappa}^{2}-\mathrm{dppm}\right)\left(\mathrm{C}^{\wedge} \mathrm{O}\right)\right]^{+}\left([4]^{+} ; \mathrm{C}^{\wedge} \mathrm{O}=\right.$ anionic bidentate $\left[\mathrm{C}(\mathrm{OMe}) \mathrm{CHC}(\mathrm{Ph}) \mathrm{O}^{-}\right.$chelate $)$ and phosphonium-ring-fused bicyclic ruthenafuran $\left[\mathrm{Ru}(\mathrm{bpy})\left(\mathrm{P}^{\wedge} \mathrm{C}^{\wedge} \mathrm{O}\right) \mathrm{Cl}\right]^{+}\left([5]^{+} ; \mathrm{P}^{\wedge} \mathrm{C}^{\wedge} \mathrm{O}=\right.$ neutral tridentate $\left[(\mathrm{Ph})_{2} \mathrm{PCH}_{2} \mathrm{P}(\mathrm{Ph})_{2} \mathrm{CCHC}(\mathrm{Ph}) \mathrm{O}\right]$ chelate $)$ was obtained when the reaction between 1 and $\mathrm{HC} \equiv \mathrm{C}(\mathrm{C}=\mathrm{O}) \mathrm{Ph}$ was performed in $\mathrm{MeOH}$. Separation of this mixture could be conveniently performed by column chromatography. 
(a)

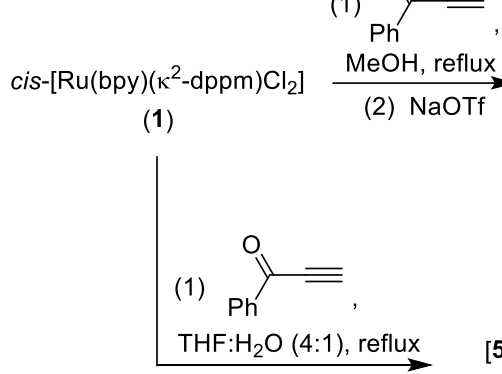
(2) $\mathrm{NaOTf}$

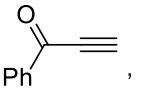

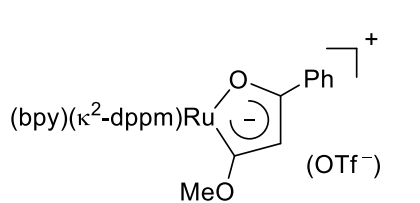

([4](OTf))

$49 \%$ yield

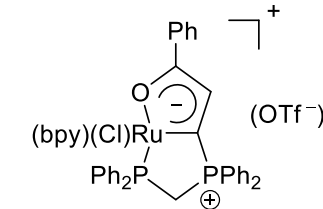

([5](OTf))

$36 \%$ yield cis-[Ru(bpy) $\left.\left(\kappa^{2}-d p p e\right) \mathrm{Cl}_{2}\right]$

(2)<smiles>C#CC(=O)c1ccccc1</smiles>

$\mathrm{MeOH}$, reflux

(2) NaOTf

$[5](\mathrm{OTf})+\left[\mathrm{Ru}(\mathrm{bpy})\left(\kappa^{2}-\mathrm{dppm}\right)(\mathrm{CO})(\mathrm{Cl})\right](\mathrm{OTf})$

$63 \%$ yield

([6](OTf)) $37 \%$ yield<smiles>C#CCOC(=O)C#C</smiles>

(2) $\mathrm{NaOTf}$

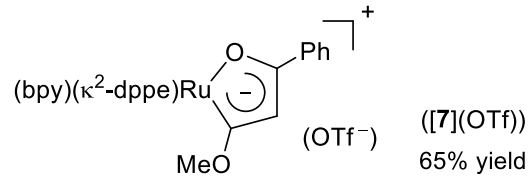

(b)

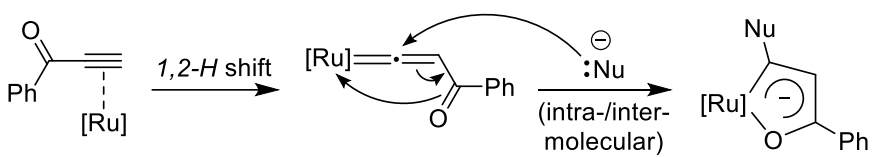

Scheme 3. (a) Reactions between phenyl ynone $\mathrm{HC} \equiv \mathrm{C}(\mathrm{C}=\mathrm{O}) \mathrm{Ph}$ and metal precursors $\mathbf{1}$ and $\mathbf{2}$, and (b) a plausible mechanism for the formation of metallafuran complexes in this work.

The molecular structures for $[4]\left(\mathrm{ClO}_{4}\right)$ and [5](OTf) $\cdot \mathrm{CH}_{2} \mathrm{Cl}_{2}$ were determined by X-ray crystallography (Figure 2). The $\alpha$-metallafuran structure (metal fragment at the $\alpha$-carbon atom of the original furan) in $[4]^{+}$is apparently a result of a rearranged $[\mathrm{HC} \equiv \mathrm{C}(\mathrm{C}=\mathrm{O}) \mathrm{Ph}+$ - OMe] structure on $\mathrm{Ru}$ center, therefore the formation of [4] $]^{+}$was due to a combination of an alkyne-vinylidene rearrangement of $\mathrm{HC} \equiv \mathrm{C}(\mathrm{C}=\mathrm{O}) \mathrm{Ph}$ on the Ru center, followed by a nucleophilic attack by ${ }^{-} \mathrm{OMe}$ (originated from the solvent $\mathrm{MeOH}$ ) and $\mathrm{O}_{\text {ynone }}$ coordination to $\mathrm{Ru}$ (Scheme 3b). The five-membered metallacycle is essentially planar with the sum of interior angle close to $540^{\circ}\left(539.5^{\circ}\right)$. The $\mathrm{Ru}-\mathrm{C}$ and $\mathrm{C}-\mathrm{C}$ distances in the metallacycle (1.964(6) and 1.413(8)-1.414(8) $\AA$, respectively) revealed the partial double bond character in the $\mathrm{Ru}-\mathrm{C}$ and $\mathrm{C}-\mathrm{C}$ bonds and supported the resonance representation (see Scheme 1c). [5] ${ }^{+}$ features a neutral tridentate $\mathrm{P}^{\wedge} \mathrm{C}^{\wedge} \mathrm{O}$ pincer ligand $\left[(\mathrm{Ph})_{2} \mathrm{PCH}_{2} \mathrm{P}(\mathrm{Ph})_{2} \mathrm{CCHC}(\mathrm{Ph}) \mathrm{O}\right]$, which could be formed as a result of an alkyne-vinylidene rearrangement of $\mathrm{HC} \equiv \mathrm{C}(\mathrm{C}=\mathrm{O}) \mathrm{Ph}$ on the $\mathrm{Ru}$ center, followed by a nucleophilic attack by a $\mathrm{P}_{\mathrm{dppm}}$ atom and $\mathrm{O}_{\text {ynone }}$ coordination to $\mathrm{Ru}($ Scheme $3 \mathrm{~b})$. The $\left[\mathrm{Ru}\left(\mathrm{P}^{\wedge} \mathrm{C}^{\wedge} \mathrm{O}\right)\right]$ moiety is a bicyclic system comprising a planar $\alpha$ metallafuran (sum of interior angle $=539.9^{\circ}$ ) fused with a five-membered $\mathrm{C}^{\wedge} \mathrm{P}$-chelate ring adopting an envelope conformation with the $\mathrm{CH}_{2}$ unit on the dppm as the flap. Again, the $\mathrm{Ru}-\mathrm{C}$ and C-C distances in the metallacycle (1.967(4) and 1.375(5)-1.441(5) $\AA$, respectively) revealed the partial double bond character in the $\mathrm{Ru}-\mathrm{C}$ and $\mathrm{C}-\mathrm{C}$ bonds. 


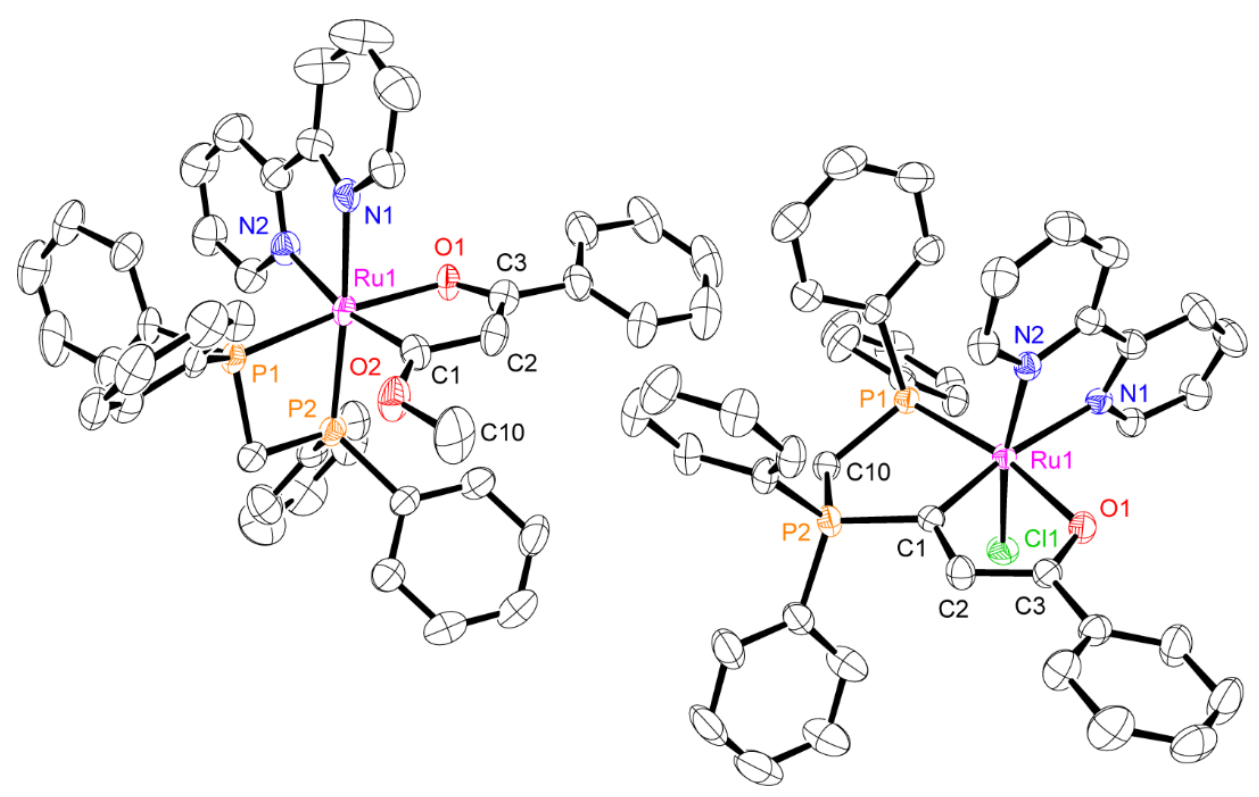

Figure 2. Perspective views of $[4]^{+}(\mathrm{left})$ and $[5]^{+}$(right) as represented by $50 \%$ probability ellipsoids (hydrogen atoms are omitted for clarity). Selected bond lengths $(\AA)$ and angles $\left({ }^{\circ}\right)$ : $[4]^{+}$: Ru1-C1 1.964(6), C1-C2 1.414(8), C2-C3 1.413(8), C3-O1 1.271(7), Ru1-O1 2.127(4), C1-O2 1.339(7), C1-Ru1O1 79.4(2), P1-Ru1-P2 72.07(5); [5] : Ru1-O1 2.166(2), Ru1-C1 1.967(4), Ru1-P1 2.2311(9), C1-C2 1.375(5), C2-C3 1.441(5), C3-O1 1.267(4), C1-P2 1.794(4), P2-C10 1.802(4), P1-C10 1.858(4), P1-Ru1-C1 89.31(10), C1-Ru1-O1 77.10(12).

The formation of $[4]^{+}$and $[5]^{+}$in the reaction between $\mathrm{HC} \equiv \mathrm{C}(\mathrm{C}=\mathrm{O}) \mathrm{Ph}$ and 1 revealed that there are two competing reactions for the $\mathrm{Ru}$-vinylidene intermediate, namely intermolecular nucleophilic attack by ${ }^{-} \mathrm{OMe}$ originated from the solvent $\mathrm{MeOH}$, and intramolecular nucleophilic attack by the auxiliary ligand dppm. However, such competition was not observed in the reaction between $\mathrm{HC} \equiv \mathrm{C}(\mathrm{C}=\mathrm{O}) \mathrm{Ph}$ and $\mathbf{2}$ in $\mathrm{MeOH}$, where methoxysubstituted ruthenafuran $\left[\mathrm{Ru}(\mathrm{bpy})\left(\mathrm{k}^{2} \text {-dppe }\right)\left(\mathrm{C}^{\wedge} \mathrm{O}\right)\right]^{+}\left([7]^{+}\right)$was found to be the only product (Scheme 3a). The difference in reactivity between $\mathbf{1}$ and $\mathbf{2}$ may be attributed to their difference in natural bite angle ( $72^{\circ}$ for $\mathrm{dppm} ; 85^{\circ}$ for dppe) [48], as bidentate ligands are known to be more labile due to the ring strain. The molecular structure for [7](OTf) $\cdot \mathrm{CH}_{2} \mathrm{Cl}_{2}$ was also determined by $\mathrm{X}$-ray crystallography (Figure 3); the structural parameters on the metallafuran moiety ( $\mathrm{Ru}-\mathrm{C}, \mathrm{C}-\mathrm{C}$, and $\mathrm{C}-\mathrm{O}$ distances are 1.982(3), 1.393(4)-1.399(4), and $1.276(3) \AA$, respectively; sum of interior angle $=539.8^{\circ}$ ) were found to be very similar to those in $[4]^{+}$.

Attempts were made to improve the yield of the phosphonium-ring-fused bicyclic ruthenafuran $[5]^{+}$by changing the reaction solvent from $\mathrm{MeOH}$ to THF. While no reaction was observed between $\mathrm{HC} \equiv \mathrm{C}(\mathrm{C}=\mathrm{O}) \mathrm{Ph}$ and $\mathbf{1}$ in dry THF, performing the reaction in a mixture of THF and $\mathrm{H}_{2} \mathrm{O}$ led to the formation of a mixture of [5] ${ }^{+}$and carbonyl complex $\left[\mathrm{Ru}(\mathrm{bpy})\left(\mathrm{k}^{2}-\mathrm{dppm}\right)(\mathrm{CO})(\mathrm{Cl})\right]^{+}\left([6]^{+}\right.$, Scheme 3a). The role of $\mathrm{H}_{2} \mathrm{O}$ in this reaction is unknown, and the carbonyl complex is likely a result of an oxidative cleavage of a vinylidene species $[49,50]$. The reaction between $\mathrm{HC} \equiv \mathrm{C}(\mathrm{C}=\mathrm{O}) \mathrm{Ph}$ and 2 in the THF $/ \mathrm{H}_{2} \mathrm{O}$ mixture gave an analogous carbonyl complex $\left[\mathrm{Ru}(\mathrm{bpy})\left(\mathrm{k}^{2} \text {-dppe }\right)(\mathrm{CO})(\mathrm{Cl})\right]^{+}\left([8]^{+}\right)$as the sole product. Both $[6]^{+}$and $[8]^{+}$featured $v_{\mathrm{CO}}\left(1994\right.$ and $1983 \mathrm{~cm}^{-1}$, respectively) and ${ }^{13} \mathrm{C}$ NMR signal (202 ppm) in the range typical for terminal carbonyl ligands. 


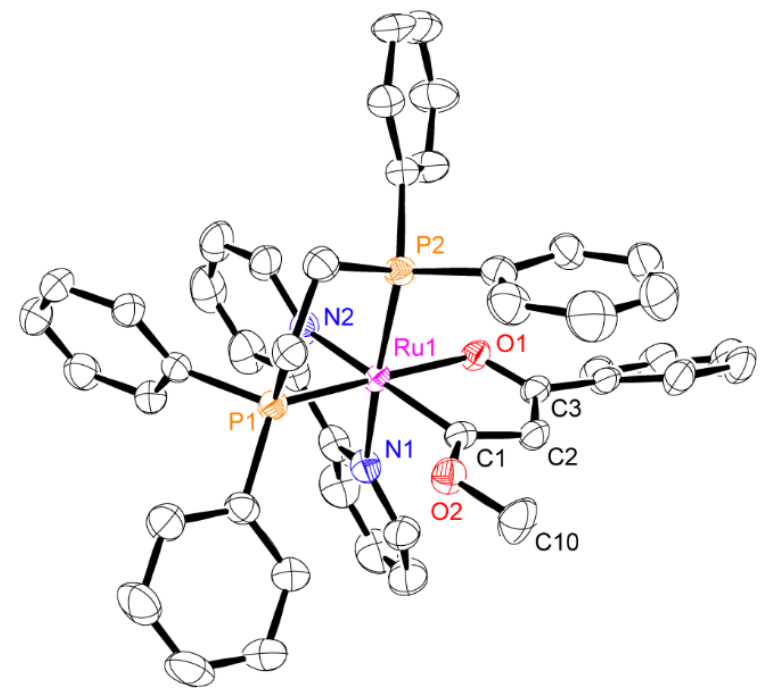

Figure 3. Perspective view of $[7]^{+}$as represented by $50 \%$ probability ellipsoids (hydrogen atoms are omitted for clarity). Selected bond lengths $(\AA)$ and angles $\left({ }^{\circ}\right)$ : Ru1-C1 1.982(3), C1-C2 1.393(4), C2-C3 1.399(4), C3-O1 1.276(3), Ru1-O1 2.139(2), C1-O2 1.344(4), C1-Ru1-O1 79.20(10), P1-Ru1-P2 84.01(3).

\subsection{Cytotoxicity Study}

The serendipitous discovery of the platinum-based anticancer complex cisplatin (cis$\left.\left[\mathrm{Pt}\left(\mathrm{NH}_{3}\right)_{2} \mathrm{Cl}_{2}\right]\right)$ and its successful approval from FDA for the treatment of cancer initiated the exploration of new metal-based chemotherapeutics. Among many metal-based anticancer agents being studied, Ru-based complexes have been proven to be promising alternatives to platinum-based drugs [51-63]. Unlike cisplatin and its derivatives, the six coordination sites of Ru complexes allow more flexibility in the design of coordination sphere for maximizing the overall efficacy of the drugs. In addition, Ru-based anticancer agents have shown far less drug resistance against different types of cancer cells than their Pt counterparts. Motivated by these reasons, the in vitro cytotoxicity of the ruthenafuran [4](OTf), [5](OTf) and [7](OTf) against cervical carcinoma (HeLa) cancer cell line was evaluated by CCK8 assay and benchmarked with cisplatin and the previously reported phosphonium-ring-fused bicyclic ruthenafuran complex $\left[\mathrm{Ru}\left(\kappa^{2}-\mathrm{dppm}\right)\left(\mathrm{P}^{\wedge} \mathrm{C}^{\wedge} \mathrm{O}\right) \mathrm{Cl}\right](\mathrm{OTf})$ $([9](\mathrm{OTf}))$. Interestingly, all the ruthenafuran complexes exhibited moderate to strong cytotoxicity, with $\mathrm{IC}_{50}$ values ranging from 0.8 to $2.8 \mu \mathrm{M}$ (Table 1$)$. Compared with cisplatin $\left(\mathrm{IC}_{50}=21.8 \mu \mathrm{M}\right)$, the ruthenafuran complexes are one order of magnitude more cytotoxic. It is worth noting that phosphonium-ring-fused ruthenafurans $\left([5]^{+}\right.$and $\left.[9]^{+}\right)$showed stronger cytotoxicity than those without phosphonium moiety.

Table 1. Cytotoxicity $\left(\mathrm{IC}_{50}, \mu \mathrm{M}\right)$ of complexes [4](OTf), [5](OTf), [7](OTf), [9](OTf) and cis$\left[\mathrm{Pt}\left(\mathrm{NH}_{3}\right)_{2} \mathrm{Cl}_{2}\right]$ against a HeLa cancer cell line ${ }^{1}$.

\begin{tabular}{cc}
\hline Complex & IC $_{\mathbf{5 0}}(\boldsymbol{\mu M})$ \\
\hline$[4](\mathrm{OTf})$ & $2.53 \pm 0.40$ \\
{$[5](\mathrm{OTf})$} & $1.60 \pm 0.20$ \\
{$[7](\mathrm{OTf})$} & $2.83 \pm 0.45$ \\
{$[9](\mathrm{OTf})$} & $0.84 \pm 0.08$ \\
cis-[Pt( $\left.\left.\mathrm{NH}_{3}\right)_{2} \mathrm{Cl}_{2}\right]$ & $21.8 \pm 1.34$ \\
\hline
\end{tabular}

${ }^{1}$ Maximum complex concentration tested: $10 \mu \mathrm{M}$ for [4](OTf) and [7](OTf); $25 \mu \mathrm{M}$ for [5](OTf) and [9](OTf); $250 \mu \mathrm{M}$ for cisplatin.

\section{Materials and Methods}

\subsection{General Procedures}

All reactions were performed under an argon atmosphere using standard Schlenk techniques unless otherwise stated. All reagents were used as received, and solvents for 
reactions were purified by a PureSolv MD5 solvent purification system. $\operatorname{cis}(\mathrm{Cl})$, cis(S)$\left[\mathrm{Ru}(\mathrm{bpy})(\mathrm{dmso}-\mathrm{S})_{2} \mathrm{Cl}_{2}\right]\left(\right.$ bpy $=2,2^{\prime}$-bipyridine; dmso = dimethyl sulfoxide) were prepared in accordance with the literature methods [64]. ${ }^{1} \mathrm{H},{ }^{1} \mathrm{H}\left\{{ }^{31} \mathrm{P}\right\},{ }^{31} \mathrm{P}\left\{{ }^{1} \mathrm{H}\right\},{ }^{13} \mathrm{C}\left\{{ }^{1} \mathrm{H}\right\},{ }^{1} \mathrm{H}-{ }^{1} \mathrm{H}$ COSY, ${ }^{1} \mathrm{H}-{ }^{1} \mathrm{H}$ NOESY, ${ }^{1} \mathrm{H}-{ }^{13} \mathrm{C}$ HSQC, ${ }^{1} \mathrm{H}-{ }^{31} \mathrm{P}$ HMBC and ${ }^{1} \mathrm{H}-{ }^{13} \mathrm{C}$ HMBC NMR spectra were recorded on Bruker 600 AVANCE III FT-NMR spectrometer. Peak positions were calibrated with solvent residue peaks as internal standard. The ${ }^{31} \mathrm{P}\left\{{ }^{1} \mathrm{H}\right\}$ NMR spectra were referenced to external $\mathrm{P}\left(\mathrm{C}_{6} \mathrm{H}_{5}\right)_{3}(-4.7 \mathrm{ppm})$ [65]. Labeling scheme for $\mathrm{H}, \mathrm{C}$ and $\mathrm{P}$ atoms in the NMR assignments is shown in Figure 4. Electrospray mass spectrometry was performed on a PESCIEX API 3200 triple quadrupole mass spectrometer, and the reported or simulated mass values correspond to the most abundant isotopic peaks in the experimental or simulated spectra, respectively. Elemental analyses were performed on an Elementar Vario Micro Cube carbon-hydrogen-nitrogen elemental microanalyzer. Fourier transform infrared (FTIR) spectra were recorded at room temperature using Pekin Elmer "Spectrum 100" FTIR Spectrometer. HeLa (human cervical carcinoma) cell line was preserved by our laboratory. Fetal bovine serum (FBS), phosphate-buffered saline (PBS), penicillinstreptomycin (PS), trypsin-EDTA and Dulbecco's modified Eagle's medium (DMEM) were purchased from Gibco BRL (Gaithersburg, MD, U.S.A.). Dimethyl sulfoxide (DMSO, >99.8\%) was obtained from Acros Organics and the cell counting kit-8 (CCK8) containing the active chemical WST8 ([2-(2-methoxy-4-nitrophenyl)-3-(4-nitrophenyl)-5-(2,4-disulfophenyl)-2H-tetrazolium] sodium salt) was purchased from Beyotime.

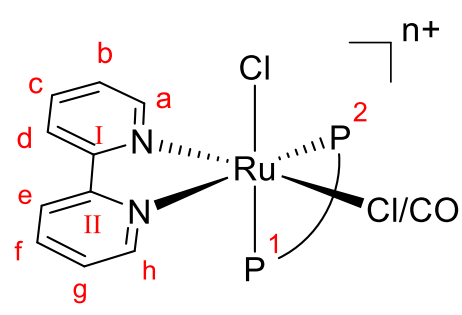

$1,2,[6]^{+},[8]^{+}$

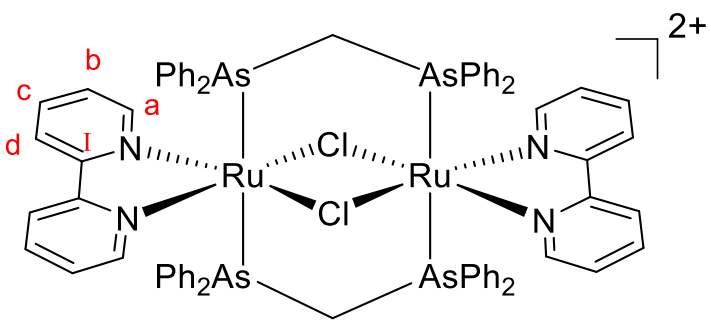

$[3]^{2+}$<smiles></smiles>

$[4]^{+},[7]^{+}$

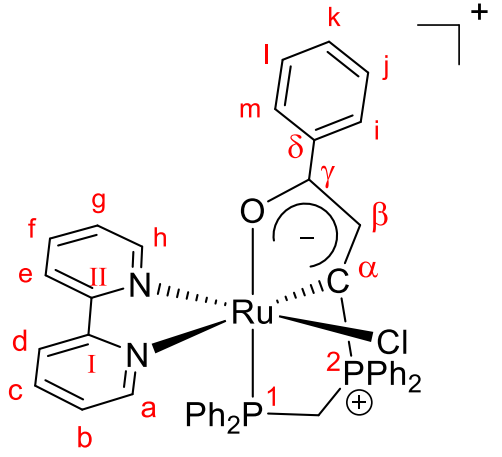

$[5]^{+}$

Figure 4. Labeling scheme for $\mathrm{H}, \mathrm{C}$ and $\mathrm{P}$ atoms in this work.

\subsection{Synthesis}

\subsubsection{Synthesis of $\mathbf{1}, \mathbf{2}$ and $[3]^{2+}$}

Method 1: A mixture of $\operatorname{cis}(\mathrm{Cl}), \operatorname{cis}(\mathrm{S})-\left[\mathrm{Ru}(\mathrm{bpy})(\mathrm{dmso}-\mathrm{S})_{2} \mathrm{Cl}_{2}\right](0.825 \mathrm{mmol})$ and 1,1bis(diphenylphosphino)methane (dppm)/1,2-bis(diphenylphosphino)ethane (dppe)/1,1bis(diphenylarsino)methane (dpam) $(0.825 \mathrm{mmol})$ was refluxed in $\mathrm{EtOH}(36 \mathrm{~mL})$ under argon for $3 \mathrm{~h}$. During refluxing, the color of the solution changed from orange to red, accompanied with the formation of red precipitates. Upon cooling to room temperature, the resultant red precipitate was collected by suction filtration, washed with cold $\mathrm{EtOH}$ $(5 \mathrm{~mL} \times 3)$ and finally $\mathrm{Et}_{2} \mathrm{O}(10 \mathrm{~mL} \times 3)$. These precipitates were pure enough for further 
reactions. Analytically pure 1,2 and $[3](\mathrm{Cl})_{2}$ red crystals were obtained by the recrystallization of the precipitates via layering of $n$-hexane onto the $\mathrm{CH}_{2} \mathrm{Cl}_{2}$ solutions of the complexes.

Method 2: A mixture of $\operatorname{cis}(\mathrm{Cl}), \operatorname{cis}(\mathrm{S})-\left[\mathrm{Ru}(\mathrm{bpy})(\mathrm{dmso}-\mathrm{S})_{2} \mathrm{Cl}_{2}\right](0.825 \mathrm{mmol})$ and dppm/ dppe/dpam (0.825 mmol) was refluxed in $\mathrm{MeOH}(50 \mathrm{~mL})$ under argon for $16 \mathrm{~h}$. During refluxing, the color of the solution changed from orange to deep red. Upon cooling to room temperature and the removal of all solvent by reduced pressure, the reaction mixture was dissolved in a minimum amount of $\mathrm{CH}_{2} \mathrm{Cl}_{2}$ and added to $\mathrm{Et}_{2} \mathrm{O}(300 \mathrm{~mL})$ to yield red precipitates. These precipitates were pure enough for further reactions and could further be recrystallized as mentioned in Method 1.

1. Yields: $92 \%$. Anal. Calcd for $\mathrm{C}_{35} \mathrm{H}_{30} \mathrm{Cl}_{2} \mathrm{~N}_{2} \mathrm{P}_{2} \mathrm{Ru}$ : C, 59.00; $\mathrm{H}, 4.24 ; \mathrm{N}, 3.93$. Found: $\mathrm{C}$ 59.12; $\mathrm{H}, 4.25 ; \mathrm{N}, 3.94 .{ }^{1} \mathrm{H}\left\{{ }^{31} \mathrm{P}\right\}$ NMR $\left(600 \mathrm{MHz}, \mathrm{CD}_{2} \mathrm{Cl}_{2}\right)$ : $84.58-4.60,5.28-5.31\left(\mathrm{~m}, 2 \mathrm{H}, \mathrm{CH}_{2}\right.$ on $\left.\mathrm{P}_{1}{ }^{\wedge} \mathrm{P}_{2}\right), 6.26-6.28\left(\mathrm{~m}, 1 \mathrm{H}, \mathrm{H}_{\mathrm{b}}\right), 7.48-7.50\left(\mathrm{~m}, 1 \mathrm{H}, \mathrm{H}_{\mathrm{c}}\right), 7.50-7.51\left(\mathrm{~m}, 1 \mathrm{H}, \mathrm{H}_{\mathrm{a}}\right), 7.54-7.56$ $\left(\mathrm{m}, 1 \mathrm{H}, \mathrm{H}_{\mathrm{g}}\right), 7.95-7.97\left(\mathrm{~m}, 1 \mathrm{H}, \mathrm{H}_{\mathrm{f}}\right), 7.99-8.01\left(\mathrm{~m}, 1 \mathrm{H}, \mathrm{H}_{\mathrm{d}}\right), 8.19-8.21\left(\mathrm{~m}, 1 \mathrm{H}, \mathrm{H}_{\mathrm{e}}\right), 9.94-9.95$ $\left(\mathrm{m}, 1 \mathrm{H}, \mathrm{H}_{\mathrm{h}}\right), 7.34-7.36,7.35-7.37,7.38-7.41,7.75-7.76,8.19-8.21(\mathrm{~m}, 10 \mathrm{H}$, protons of $\mathrm{Ph}$ rings on $\left.\mathrm{P}_{2}\right), 6.75-6.76,6.93-6.96,7.09-7.11,7.21-7.24,7.28-7.31(\mathrm{~m}, 10 \mathrm{H}$, protons of $\mathrm{Ph}$ rings on $\left.\mathrm{P}_{1}\right) \cdot{ }^{13} \mathrm{C}\left\{{ }^{1} \mathrm{H}\right\} \mathrm{NMR}\left(151 \mathrm{MHz}, \mathrm{CD}_{2} \mathrm{Cl}_{2}\right): \delta 44.23\left(\mathrm{CH}_{2}\right.$ on $\left.\mathrm{P}_{1}{ }^{\wedge} \mathrm{P}_{2}\right), 122.03\left(\mathrm{C}_{\mathrm{e}}\right), 122.47$ $\left(\mathrm{C}_{\mathrm{d}}\right), 124.50\left(\mathrm{C}_{\mathrm{b}}\right), 125.23\left(\mathrm{C}_{\mathrm{g}}\right), 134.91\left(\mathrm{C}_{\mathrm{c}}\right), 136.64\left(\mathrm{C}_{\mathrm{f}}\right), 152.39\left(\mathrm{C}_{\mathrm{h}}\right), 155.99\left(\mathrm{C}_{\mathrm{a}}\right), 156.72\left(\mathrm{C}_{\mathrm{II}}\right)$, $158.93\left(\mathrm{C}_{\mathrm{I}}\right), 128.04,129.82,130.04,131.78,133.66,134.23,136.20\left(12 \mathrm{C}\right.$ of $\mathrm{Ph}$ rings on $\mathrm{P}_{2}$ ), $128.33,128.63,129.60,129.94,130.75,132.14,134.50\left(12 \mathrm{C}\right.$ of $\mathrm{Ph}$ rings on $\left.\mathrm{P}_{1}\right) \cdot{ }^{31} \mathrm{P}\left\{{ }^{1} \mathrm{H}\right\} \mathrm{NMR}$ $\left(243 \mathrm{MHz}, \mathrm{CD}_{2} \mathrm{Cl}_{2}\right): \delta 2.66\left(\mathrm{~d}, \mathrm{~J}_{\mathrm{P} 2 \mathrm{P} 1}=67.2 \mathrm{~Hz}, \mathrm{P}_{2}\right), 10.11\left(\mathrm{~d}, \mathrm{~J}_{\mathrm{P} 1 \mathrm{P} 2}=67.2 \mathrm{~Hz}, \mathrm{P}_{1}\right)$, ESI-MS $\mathrm{m} / \mathrm{z}$ calcd. for $\mathrm{C}_{35} \mathrm{H}_{30} \mathrm{ClN}_{2} \mathrm{P}_{2} \mathrm{Ru}\left([1-\mathrm{Cl}]^{+}\right)$: 677.1, Found: 677.0.

2. Yields: $93 \%$. Anal. Calcd for $\mathrm{C}_{36} \mathrm{H}_{32} \mathrm{Cl}_{2} \mathrm{~N}_{2} \mathrm{P}_{2} \mathrm{Ru}$ : C, 59.51; $\mathrm{H}, 4.44 ; \mathrm{N}, 3.86$. Found: $\mathrm{C}$, 58.98; $\mathrm{H}, 4.42 ; \mathrm{N}, 3.86 .{ }^{1} \mathrm{H}\left\{{ }^{31} \mathrm{P}\right\}$ NMR $\left(600 \mathrm{MHz}, \mathrm{CD}_{2} \mathrm{Cl}_{2}\right): \delta 2.48-2.53,2.65-2.70,3.03-3.06$, 3.32-3.35 (m, 4H, $\left(\mathrm{CH}_{2}\right)_{2}$ on $\left.\mathrm{P}_{1}{ }^{\wedge} \mathrm{P}_{2}\right), 6.05-6.07\left(\mathrm{~m}, 1 \mathrm{H}, \mathrm{H}_{\mathrm{b}}\right), 7.20-7.21\left(\mathrm{~m}, 1 \mathrm{H}, \mathrm{H}_{\mathrm{a}}\right), 7.37-7.40$ $\left(\mathrm{m}, 1 \mathrm{H}, \mathrm{H}_{\mathrm{c}}\right), 7.53-7.56\left(\mathrm{~m}, 1 \mathrm{H}, \mathrm{H}_{\mathrm{g}}\right), 7.92-7.93\left(\mathrm{~m}, 1 \mathrm{H}, \mathrm{H}_{\mathrm{d}}\right), 7.98-8.01\left(\mathrm{~m}, 1 \mathrm{H}, \mathrm{H}_{\mathrm{f}}\right), 8.19-8.23(\mathrm{~m}$, $\left.1 \mathrm{H}, \mathrm{H}_{\mathrm{e}}\right), 9.82-9.83\left(\mathrm{~m}, 1 \mathrm{H}, \mathrm{H}_{\mathrm{h}}\right), 7.24-7.29,7.31-7.34,8.03-8.04,8.23-8.24(\mathrm{~m}, 10 \mathrm{H}$, protons of Ph rings on $\left.\mathrm{P}_{2}\right), 6.51-6.52,6.81-6.84,6.97-6.99,7.18-7.21,7.53-7.55(\mathrm{~m}, 10 \mathrm{H}$, protons of Ph rings on $\left.\mathrm{P}_{1}\right) \cdot{ }^{13} \mathrm{C}\left\{{ }^{1} \mathrm{H}\right\}$ NMR $\left(151 \mathrm{MHz}, \mathrm{CD}_{2} \mathrm{Cl}_{2}\right): \delta 24.35,26.33\left(\left(\mathrm{CH}_{2}\right)_{2}\right.$ on $\left.\mathrm{P}_{1}{ }^{\wedge} \mathrm{P}_{2}\right), 121.61$ $\left(\mathrm{C}_{\mathrm{e}}\right), 122.31\left(\mathrm{C}_{\mathrm{d}}\right), 123.50\left(\mathrm{C}_{\mathrm{b}}\right), 125.06\left(\mathrm{C}_{\mathrm{g}}\right), 134.24\left(\mathrm{C}_{\mathrm{c}}\right), 136.63\left(\mathrm{C}_{\mathrm{f}}\right), 152.29\left(\mathrm{C}_{\mathrm{h}}\right), 156.73\left(\mathrm{C}_{\mathrm{II}}\right)$, $156.80\left(\mathrm{C}_{\mathrm{a}}\right), 159.07\left(\mathrm{C}_{\mathrm{I}}\right), 127.31,128.58,129.36,129.78,132.35,132.71,135.32(12 \mathrm{C}$ of $\mathrm{Ph}$ rings on $\left.\mathrm{P}_{2}\right), 127.66,128.13,128.63,129.72,132.77,133.57,135.32\left(12 \mathrm{C}\right.$ of $\mathrm{Ph}$ rings on $\left.\mathrm{P}_{1}\right) .{ }^{31} \mathrm{P}\left\{{ }^{1} \mathrm{H}\right\}$ $\operatorname{NMR}\left(243 \mathrm{MHz}, \mathrm{CD}_{2} \mathrm{Cl}_{2}\right): \delta 61.38\left(\mathrm{~d}, J_{\mathrm{P} 2 \mathrm{P} 1}=22.4 \mathrm{~Hz}, \mathrm{P}_{2}\right), 68.42\left(\mathrm{~d}, \mathrm{~J}_{\mathrm{P} 1 \mathrm{P} 2}=22.4 \mathrm{~Hz}, \mathrm{P}_{1}\right)$. ESI-MS m/z calcd. for $\mathrm{C}_{36} \mathrm{H}_{32} \mathrm{ClN}_{2} \mathrm{P}_{2} \mathrm{Ru}\left(\left[2-\mathrm{Cl}^{+}\right)\right.$: 691.1, Found: 691.2.

[3] $(\mathrm{OTf})_{2}$. Yields: $97 \%$. Anal. Calcd for $\mathrm{C}_{72} \mathrm{H}_{60} \mathrm{Cl}_{2} \mathrm{~F}_{6} \mathrm{~N}_{4} \mathrm{O}_{6} \mathrm{~S}_{2} \mathrm{As}_{4} \mathrm{Ru}_{2}$ : C, 47.30; $\mathrm{H}, 3.31$; $\mathrm{N}$, 3.06. Found: $\mathrm{C}, 47.24 ; \mathrm{H}, 3.30 ; \mathrm{N}, 3.05 .{ }^{1} \mathrm{H}$ NMR $\left(600 \mathrm{MHz}, \mathrm{CD}_{3} \mathrm{CN}\right): \delta 4.00\left(\mathrm{~s}, 4 \mathrm{H}, \mathrm{CH}_{2}\right.$ on dpam), 7.01-7.03 (m, 4H, $\left.\mathrm{H}_{\mathrm{b}}\right), 7.46-7.49\left(\mathrm{~m}, 4 \mathrm{H}, \mathrm{H}_{\mathrm{c}}\right), 7.68-7.70\left(\mathrm{~m}, 4 \mathrm{H}, \mathrm{H}_{\mathrm{d}}\right), 8.90-8.91(\mathrm{~m}$, $\left.4 \mathrm{H}, \mathrm{H}_{\mathrm{a}}\right), 6.91-6.97,7.11-7.14\left(\mathrm{~m}, 40 \mathrm{H}\right.$, protons of Ph rings on dpam). $\left.{ }^{13} \mathrm{C}_{\{}{ }^{1} \mathrm{H}\right\} \mathrm{NMR}(151$ $\left.\mathrm{MHz}, \mathrm{CD}_{3} \mathrm{CN}\right): \delta 16.22\left(\mathrm{CH}_{2}\right.$ on dpam $), 124.16\left(\mathrm{C}_{\mathrm{d}}\right), 126.84\left(\mathrm{C}_{\mathrm{b}}\right), 136.64\left(\mathrm{C}_{\mathrm{c}}\right), 154.06\left(\mathrm{C}_{\mathrm{a}}\right)$, $159.10\left(\mathrm{C}_{\mathrm{I}}\right), 129.66,130.75,132.16,133.08$ (48C of Ph rings on dpam). ESI-MS m/z calcd. for $\mathrm{C}_{70} \mathrm{H}_{60} \mathrm{Cl}_{2} \mathrm{~N}_{4} \mathrm{As}_{4} \mathrm{Ru}_{2}\left([3]^{2+}\right)$ : 765.0, Found: 764.9 .

\subsubsection{Synthesis of [4](OTf) and [5](OTf)}

A mixture of 1-phenylprop-2-yn-1-one $(\mathrm{HC} \equiv \mathrm{C}(\mathrm{C}=\mathrm{O}) \mathrm{Ph}, 0.14 \mathrm{mmol})$ and cis-[Ru(bpy) $\left.(\mathrm{dppm}) \mathrm{Cl}_{2}\right](0.07 \mathrm{mmol})$ were refluxed in $\mathrm{MeOH}(50 \mathrm{~mL})$ under argon for $16 \mathrm{~h}$, during which the metal precursor gradually dissolved and the color of the reaction mixture changed from red to deep red. Upon cooling to room temperature, a saturated aqueous NaOTf solution $(5 \mathrm{~mL})$ was added into the reaction mixture, and the mixture was concentrated to about $5 \mathrm{~mL}$ by reduced pressure to give a suspension of brown red solids. The solids were then collected by suction filtration, washed with deionized water $(10 \mathrm{~mL} \times 3)$ and finally $\mathrm{Et}_{2} \mathrm{O}$ $(10 \mathrm{~mL} \times 3)$. The separation of the crude products [4](OTf) and [5](OTf) was performed by column chromatography. Conditions: basic alumina, $\mathrm{CH}_{2} \mathrm{Cl}_{2} /\left(\mathrm{CH}_{3}\right)_{2} \mathrm{CO} 9: 1(v / v)$ as eluent gave [4](OTf) as the first band (orange); the second band (purple) containing [5](OTf) was then eluted with a $\mathrm{CH}_{2} \mathrm{Cl}_{2} /\left(\mathrm{CH}_{3}\right)_{2} \mathrm{CO} 7: 3(v / v)$ mixture. Analytically pure orange crystals 
of [4](OTf) and deep purple crystals of [5](OTf) were obtained by the recrystallization of the collected bands via layering of $n$-hexane onto a $\mathrm{CH}_{2} \mathrm{Cl}_{2}$ solution of the complexes.

[4](OTf). Yield: 49\%. Anal. Calcd for $\mathrm{C}_{46} \mathrm{H}_{39} \mathrm{~F}_{3} \mathrm{~N}_{2} \mathrm{O}_{5} \mathrm{P}_{2} \mathrm{SRu}$ : C, 58.04; H, 4.13; N, 2.94. Found: $\mathrm{C}, 58.02 ; \mathrm{H}, 4.12 ; \mathrm{N}, 2.94 .{ }^{1} \mathrm{H}\left\{{ }^{31} \mathrm{P}\right\} \mathrm{NMR}\left(600 \mathrm{MHz},\left(\mathrm{CD}_{3}\right)_{2} \mathrm{CO}\right): \delta 3.43\left(\mathrm{~s}, 3 \mathrm{H}, \mathrm{OCH}_{3}\right)$, 5.09-5.12, 5.35-5.38 (m, 2H, $\mathrm{CH}_{2}$ on $\left.\mathrm{P}_{1}{ }^{\wedge} \mathrm{P}_{2}\right), 6.62\left(\mathrm{~s}, 1 \mathrm{H}, \mathrm{H}_{\beta}\right), 7.08-7.10\left(\mathrm{~m}, 1 \mathrm{H}, \mathrm{H}_{\mathrm{g}}\right), 7.34-7.36$ $\left(\mathrm{m}, 2 \mathrm{H}, \mathrm{H}_{1}+\mathrm{H}_{\mathrm{j}}\right), 7.42-7.45\left(\mathrm{~m}, 1 \mathrm{H}, \mathrm{H}_{\mathrm{k}}\right), 7.55-7.57\left(\mathrm{~m}, 1 \mathrm{H}, \mathrm{H}_{\mathrm{b}}\right), 7.71-7.72\left(\mathrm{~m}, 2 \mathrm{H}, \mathrm{H}_{\mathrm{i}}+\mathrm{H}_{\mathrm{m}}\right)$, 7.96-7.97 (m, 1H, $\left.\mathrm{H}_{\mathrm{h}}\right), 8.64-8.65\left(\mathrm{~m}, 3 \mathrm{H}, \mathrm{H}_{\mathrm{a}}+\mathrm{H}_{\mathrm{d}}+\mathrm{H}_{\mathrm{e}}\right), 8.09-8.12\left(\mathrm{~m}, 1 \mathrm{H}, \mathrm{H}_{\mathrm{f}}\right), 8.14-8.17(\mathrm{~m}$, $\left.1 \mathrm{H}, \mathrm{H}_{\mathrm{C}}\right), 7.26-7.28,7.36-7.37,7.38-7.41,7.43-7.46,7.64-7.65(\mathrm{~m}, 10 \mathrm{H}$, protons of $\mathrm{Ph}$ rings on $\left.\mathrm{P}_{2}\right), 7.04-7.05,7.17-7.20,7.38-7.42,7.51-7.54\left(\mathrm{~m}, 10 \mathrm{H}\right.$, protons of $\mathrm{Ph}$ rings on $\left.\mathrm{P}_{1}\right) .{ }^{13} \mathrm{C}\left\{{ }^{1} \mathrm{H}\right\}$ $\operatorname{NMR}\left(151 \mathrm{MHz},\left(\mathrm{CD}_{3}\right)_{2} \mathrm{CO}\right): \delta 43.12\left(\mathrm{CH}_{2}\right.$ on $\left.\mathrm{P}_{1}{ }^{\wedge} \mathrm{P}_{2}\right), 58.90\left(\mathrm{OCH}_{3}\right), 107.36\left(\mathrm{C}_{\beta}\right), 123.84\left(\mathrm{C}_{\mathrm{d}}\right)$, $124.24\left(\mathrm{C}_{\mathrm{e}}\right), 126.62\left(\mathrm{C}_{\mathrm{g}}\right), 127.18\left(\mathrm{C}_{\mathrm{b}}\right), 128.36\left(\mathrm{C}_{\mathrm{i}}+\mathrm{C}_{\mathrm{m}}\right), 129.28\left(\mathrm{C}_{\mathrm{l}}+\mathrm{C}_{\mathrm{j}}\right), 132.15\left(\mathrm{C}_{\mathrm{k}}\right), 137.99$ $\left(C_{\delta}\right), 139.09\left(C_{f}\right), 139.25\left(C_{c}\right), 153.86\left(C_{h}\right), 155.37\left(C_{a}\right), 156.59\left(C_{I I}\right), 157.31\left(C_{I}\right), 198.61\left(C_{\gamma}\right)$, $255.00\left(C_{\alpha}\right), 129.08,129.23,130.14,130.71,131.40,131.59,132.57,134.09$ (12C of Ph rings on $\left.\mathrm{P}_{2}\right), 129.23,130.38,130.71,131.47,132.08,135.93,136.18\left(12 \mathrm{C}\right.$ of $\mathrm{Ph}$ rings on $\left.\mathrm{P}_{1}\right) .{ }^{31} \mathrm{P}\left\{{ }^{1} \mathrm{H}\right\}$ NMR (243 MHz, $\left.\left(\mathrm{CD}_{3}\right)_{2} \mathrm{CO}\right): \delta 6.10\left(\mathrm{~d}, J_{\mathrm{P} 2 \mathrm{P} 1}=70.3 \mathrm{~Hz}, \mathrm{P}_{1}\right), 12.30\left(\mathrm{~d}, J_{\mathrm{P} 1 \mathrm{P} 2}=70.3 \mathrm{~Hz}, \mathrm{P}_{2}\right)$. ESI-MS $m / z$ calcd. for $\mathrm{C}_{45} \mathrm{H}_{39} \mathrm{~N}_{2} \mathrm{O}_{2} \mathrm{P}_{2} \mathrm{Ru}\left([4]^{+}\right)$: 802.8, Found: 803.2.

[5](OTf). Yield: 36\%. Anal. Calcd for $\mathrm{C}_{45} \mathrm{H}_{36} \mathrm{ClF}_{3} \mathrm{~N}_{2} \mathrm{O}_{4} \mathrm{P}_{2} \mathrm{SRu}: \mathrm{C}, 56.52 ; \mathrm{H}, 3.79 ; \mathrm{N}$, 2.93. Found: C, 56.41; H, 3.78; N, 2.92. ${ }^{1} \mathrm{H}\left\{{ }^{31} \mathrm{P}\right\}$ NMR (600 MHz, $\left.\left(\mathrm{CD}_{3}\right)_{2} \mathrm{CO}\right): \delta 4.23-4.25$, 5.03-5.06 (m, 2H, $\mathrm{CH}_{2}$ on $\left.\mathrm{P}_{1}{ }^{\wedge} \mathrm{P}_{2}\right), 6.92-6.94\left(\mathrm{~m}, 1 \mathrm{H}, \mathrm{H}_{\mathrm{g}}\right), 7.39-7.41\left(\mathrm{~m}, 2 \mathrm{H}, \mathrm{H}_{\mathrm{j}}+\mathrm{H}_{1}\right), 7.52-7.55$ $\left(\mathrm{m}, 1 \mathrm{H}, \mathrm{H}_{\mathrm{k}}\right), 7.72-7.74\left(\mathrm{~m}, 1 \mathrm{H}, \mathrm{H}_{\mathrm{h}}\right), 7.78-7.82\left(\mathrm{~m}, 1 \mathrm{H}, \mathrm{H}_{\mathrm{f}}\right), 7.92-7.94\left(\mathrm{~m}, 1 \mathrm{H}, \mathrm{H}_{\mathrm{b}}\right), 8.03-8.04$ $\left(\mathrm{m}, 2 \mathrm{H}, \mathrm{H}_{\mathrm{i}}+\mathrm{H}_{\mathrm{m}}\right), 8.31-8.34\left(\mathrm{~m}, 1 \mathrm{H}, \mathrm{H}_{\mathrm{c}}\right), 8.38-8.39\left(\mathrm{~m}, 1 \mathrm{H}, \mathrm{H}_{\mathrm{e}}\right), 8.63-8.64\left(\mathrm{~m}, 1 \mathrm{H}, \mathrm{H}_{\mathrm{d}}\right)$, $9.01\left(\mathrm{~s}, 1 \mathrm{H}, \mathrm{H}_{\beta}\right), 9.78-9.79\left(\mathrm{~m}, 1 \mathrm{H}, \mathrm{H}_{\mathrm{a}}\right), 7.56-7.59,7.79-7.81,7.87-7.90,7.98-8.00,8.44-8.46$ $\left(\mathrm{m}, 10 \mathrm{H}\right.$, protons of $\mathrm{Ph}$ rings on $\left.\mathrm{P}_{1}\right), 6.46-6.47,6.73-6.75,7.02-7.05,7.26-7.29,7.37-7.40$, 7.64-7.65 (m, 10H, protons of Ph rings on $\left.\mathrm{P}_{2}\right) .{ }^{13} \mathrm{C}\left\{{ }^{1} \mathrm{H}\right\} \mathrm{NMR}\left(151 \mathrm{MHz},\left(\mathrm{CD}_{3}\right)_{2} \mathrm{CO}\right): \delta 35.31$ $\left(\mathrm{CH}_{2}\right.$ on $\left.\mathrm{P}_{1}{ }^{\wedge} \mathrm{P}_{2}\right), 124.35\left(\mathrm{C}_{\mathrm{d}}\right), 125.00\left(\mathrm{C}_{\mathrm{e}}\right), 128.06\left(\mathrm{C}_{\mathrm{g}}\right), 128.20\left(\mathrm{C}_{\mathrm{b}}\right), 130.39\left(\mathrm{C}_{\mathrm{j}}+\mathrm{C}_{\mathrm{l}}\right), 130.41$ $\left(C_{i}+C_{m}\right), 134.16\left(C_{k}\right), 138.11\left(C_{\delta}\right), 138.49\left(C_{f}\right), 139.77\left(C_{c}\right), 144.21\left(C_{\beta}\right), 152.57\left(C_{a}\right), 155.82$ $\left(C_{\mathrm{I}}\right), 155.98\left(\mathrm{C}_{\mathrm{h}}\right), 158.68\left(\mathrm{C}_{\mathrm{II}}\right), 198.55\left(\mathrm{C}_{\gamma}\right), 239.91\left(\mathrm{C}_{\alpha}\right), 120.26,131.20,132.21,135.19,135.26$, $135.67,135.74,136.47$ (12C of $\mathrm{Ph}$ rings on $\left.\mathrm{P}_{1}\right), 129.63,129.66,130.98,131.78,131.89,134.53$, 135.19 (12C of Ph rings on $\left.\mathrm{P}_{2}\right) .{ }^{31} \mathrm{P}\left\{{ }^{1} \mathrm{H}\right\} \mathrm{NMR}\left(243 \mathrm{MHz},\left(\mathrm{CD}_{3}\right)_{2} \mathrm{CO}\right): \delta 25.09-25.39\left(\mathrm{~m}, \mathrm{P}_{2}\right)$, 61.16-61.58 (m, $\left.\mathrm{P}_{1}\right)$. ESI-MS $m / z$ calcd. for $\mathrm{C}_{44} \mathrm{H}_{36} \mathrm{ClN}_{2} \mathrm{OP}_{2} \mathrm{Ru}\left([5]^{+}\right)$: 807.3, Found: 807.1.

\subsubsection{Synthesis of [5](OTf) and [6](OTf)}

The synthesis of [5](OTf) and [6](OTf) was similar to that of [4](OTf), except that a mixture of THF and $\mathrm{H}_{2} \mathrm{O}$ (40 and $10 \mathrm{~mL}$, respectively) was used as the reaction solvent. During refluxing, the metal precursor gradually dissolved and the color of the reaction mixture changed from yellowish red to purple red. Upon cooling to room temperature, the mixture was concentrated to about $10 \mathrm{~mL}$ by reduced pressure and the resultant aqueous solution was washed with $\mathrm{Et}_{2} \mathrm{O}(10 \mathrm{~mL} \times 2)$. A saturated aqueous NaOTf solution $(5 \mathrm{~mL})$ was added to the aqueous phase, and the resultant mixture was then extracted with $\mathrm{CH}_{2} \mathrm{Cl}_{2}$ $(30 \mathrm{~mL} \times 3)$. The organic phases were dried over anhydrous $\mathrm{MgSO}_{4}$. After the removal of $\mathrm{MgSO}_{4}$ by a simple filtration, the filtrate was concentrated to give a dark purple red oil. The separation of the crude products [5](OTf) and [6](OTf) was performed by column chromatography. Conditions: basic alumina, $\mathrm{CH}_{2} \mathrm{Cl}_{2} /\left(\mathrm{CH}_{3}\right)_{2} \mathrm{CO} 7: 3(v / v)$ as eluent gave [5](OTf) as the first band (purple); the second band (yellow) containing [6](OTf) was then eluted with a $\mathrm{CH}_{2} \mathrm{Cl}_{2} /\left(\mathrm{CH}_{3}\right)_{2} \mathrm{CO} 5: 5(v / v)$ mixture. The yield of [5](OTf) prepared by this method was found to be $63 \%$.

[6](OTf). Yield: 37\%. Anal. Calcd for $\mathrm{C}_{37} \mathrm{H}_{30} \mathrm{ClF}_{3} \mathrm{~N}_{2} \mathrm{O}_{4} \mathrm{P}_{2} \mathrm{SRu}$ : C, 52.03; H, 3.54; N, 3.28 . Found: $\mathrm{C}, 51.91 ; \mathrm{H}, 3.54 ; \mathrm{N}, 3.28 .{ }^{1} \mathrm{H}\left\{{ }^{31} \mathrm{P}\right\} \mathrm{NMR}\left(600 \mathrm{MHz}, \mathrm{CD}_{2} \mathrm{Cl}_{2}\right): \delta 4.84-4.87,5.63-5.65$ $\left(\mathrm{m}, 2 \mathrm{H}, \mathrm{CH}_{2}\right.$ on $\left.\mathrm{P}_{1}{ }^{\wedge} \mathrm{P}_{2}\right), 6.85-6.86\left(\mathrm{~m}, 1 \mathrm{H}, \mathrm{H}_{\mathrm{b}}\right), 7.72-7.74\left(\mathrm{~m}, 1 \mathrm{H}, \mathrm{H}_{\mathrm{g}}\right), 7.80-7.81\left(\mathrm{~m}, 1 \mathrm{H}, \mathrm{H}_{\mathrm{a}}\right)$, 7.83-7.86 $\left(\mathrm{m}, 1 \mathrm{H}, \mathrm{H}_{\mathrm{c}}\right), 8.13-8.15\left(\mathrm{~m}, 1 \mathrm{H}, \mathrm{H}_{\mathrm{d}}\right), 8.18-8.21\left(\mathrm{~m}, 1 \mathrm{H}, \mathrm{H}_{\mathrm{f}}\right), 8.34-8.35\left(\mathrm{~m}, 1 \mathrm{H}, \mathrm{H}_{\mathrm{e}}\right)$, 9.32-9.33 $\left(\mathrm{m}, 1 \mathrm{H}, \mathrm{H}_{\mathrm{h}}\right), 7.48-7.49,7.58-7.62,7.98-7.99,8.22-8.23(\mathrm{~m}, 10 \mathrm{H}$, protons of $\mathrm{Ph}$ rings on $\left.\mathrm{P}_{2}\right), 6.85-6.86,7.04-7.07,7.20-7.22,7.47-7.48,7.51-7.53,7.56-7.57,(\mathrm{~m}, 10 \mathrm{H}$, protons of $\mathrm{Ph}$ rings on $\left.\mathrm{P}_{1}\right) .{ }^{13} \mathrm{C}\left\{{ }^{1} \mathrm{H}\right\} \mathrm{NMR}\left(151 \mathrm{MHz}, \mathrm{CD}_{2} \mathrm{Cl}_{2}\right): \delta 43.27\left(\mathrm{CH}_{2}\right.$ on $\left.\mathrm{P}_{1}{ }^{\wedge} \mathrm{P}_{2}\right), 124.08\left(\mathrm{C}_{\mathrm{d}}\right), 124.56$ $\left(C_{e}\right), 127.04\left(C_{b}\right), 127.89\left(C_{g}\right), 139.93\left(C_{f}\right), 140.00\left(C_{c}\right), 152.49\left(C_{a}\right), 153.44\left(C_{h}\right), 155.20\left(C_{I I}\right)$, 
155.66( $\left.\mathrm{C}_{\mathrm{I}}\right), 202.56(\mathrm{CO}), 130.32,130.55,131.55,132.00,132.81$ (12C of Ph rings on $\left.\mathrm{P}_{2}\right), 128.43$, $129.69,129.75,130.03,130.39,131.87,131.95,132.60,\left(12 \mathrm{C}\right.$ of $\mathrm{Ph}$ rings on $\left.\mathrm{P}_{1}\right) .{ }^{31} \mathrm{P}\left\{{ }^{1} \mathrm{H}\right\} \mathrm{NMR}$ $\left(243 \mathrm{MHz}, \mathrm{CD}_{2} \mathrm{Cl}_{2}\right): \delta-9.78\left(\mathrm{~d}, J_{\mathrm{P} 2 \mathrm{P} 1}=48.5 \mathrm{~Hz}, \mathrm{P}_{2}\right), 1.24\left(\mathrm{~d}, J_{\mathrm{P} 1 \mathrm{P} 2}=48.5 \mathrm{~Hz}, \mathrm{P}_{1}\right) . \operatorname{IR}(\mathrm{KBr}$, $\left.\mathrm{cm}^{-1}\right): v_{\mathrm{CO}}=1994$. ESI-MS $m / z$ calcd. for $\mathrm{C}_{36} \mathrm{H}_{30} \mathrm{ClN}_{2} \mathrm{OP}_{2} \mathrm{Ru}\left([6]^{+}\right)$: 705.1, Found: 705.1 .

\subsubsection{Synthesis of [7](OTf)}

The procedure for the synthesis of [7](OTf) was the same as that for the synthesis of [4](OTf), except that cis-[Ru(bpy)(dppe) $\left.\mathrm{Cl}_{2}\right]$ was used instead of $c$ is-[Ru(bpy)(dppm) $\left.\mathrm{Cl}_{2}\right]$. The color of the reaction mixture was found to be orange during refluxing. The crude product, [7](OTf), was eluted as an orange band using a $\mathrm{CH}_{2} \mathrm{Cl}_{2} /\left(\mathrm{CH}_{3}\right)_{2} \mathrm{CO} 8: 2(v / v)$ mixture as eluent on a basic alumina column. Analytically pure orange crystals of [7](OTf) were obtained by the recrystallization of the collected band via layering of $n$-hexane onto a $\mathrm{CH}_{2} \mathrm{Cl}_{2}$ solution of the complex.

[7](OTf). Yield: 65\%. Anal. Calcd for $\mathrm{C}_{47} \mathrm{H}_{41} \mathrm{~F}_{3} \mathrm{~N}_{2} \mathrm{O}_{5} \mathrm{P}_{2} \mathrm{SRu}$ : C, 58.44; H, 4.28; N, 2.90 . Found: $\mathrm{C}, 58.33 ; \mathrm{H}, 4.26 ; \mathrm{N}, 2.89 .{ }^{1} \mathrm{H}\left\{{ }^{31} \mathrm{P}\right\} \mathrm{NMR}\left(600 \mathrm{MHz}, \mathrm{CD}_{2} \mathrm{Cl}_{2}\right): \delta 2.35-2.39,2.65-2.69$, 3.46-3.52 (m, 4H, $\left(\mathrm{CH}_{2}\right)_{2}$ on $\left.\mathrm{P}_{1}{ }^{\wedge} \mathrm{P}_{2}\right), 3.21\left(\mathrm{~s}, 3 \mathrm{H}, \mathrm{OCH}_{3}\right), 5.97\left(\mathrm{~s}, 1 \mathrm{H}, \mathrm{H}_{\beta}\right), 6.52-6.54(\mathrm{~m}$, $\left.1 \mathrm{H}, \mathrm{H}_{\mathrm{g}}\right), 7.27-7.33\left(\mathrm{~m}, 2 \mathrm{H}, \mathrm{H}_{1}+\mathrm{H}_{\mathrm{j}}\right), 7.37-7.39\left(\mathrm{~m}, 1 \mathrm{H}, \mathrm{H}_{\mathrm{k}}\right), 7.42-7.46\left(\mathrm{~m}, 2 \mathrm{H}, \mathrm{H}_{\mathrm{b}}+\mathrm{H}_{\mathrm{h}}\right)$, 7.57-7.58 (m, 2H, $\left.\mathrm{H}_{\mathrm{i}}+\mathrm{H}_{\mathrm{m}}\right), 7.73-7.75\left(\mathrm{~m}, 1 \mathrm{H}, \mathrm{H}_{\mathrm{f}}\right), 8.03-8.06\left(\mathrm{~m}, 1 \mathrm{H}, \mathrm{H}_{\mathrm{c}}\right), 8.17-8.19(\mathrm{~m}, 1 \mathrm{H}$, $\left.\mathrm{H}_{\mathrm{e}}\right), 8.34-8.35\left(\mathrm{~m}, 1 \mathrm{H}, \mathrm{H}_{\mathrm{d}}\right), 8.67-8.68\left(\mathrm{~m}, 1 \mathrm{H}, \mathrm{H}_{\mathrm{a}}\right)$, 6.95-6.97, 7.07-7.10, 7.19-7.21, 7.36-7.39, 7.90-7.92 $\left(\mathrm{m}, 10 \mathrm{H}\right.$, protons of $\mathrm{Ph}$ rings on $\left.\mathrm{P}_{1}\right), 6.54-6.58,6.84-6.86,6.97-7.00,7.28-7.34$, 7.43-7.48 (m, 10H, protons of Ph rings on $\left.\mathrm{P}_{2}\right) .{ }^{13} \mathrm{C}\left\{{ }^{1} \mathrm{H}\right\} \mathrm{NMR}\left(151 \mathrm{MHz}, \mathrm{CD}_{2} \mathrm{Cl}_{2}\right): \delta 26.34$, $28.88\left(\left(\mathrm{CH}_{2}\right)_{2}\right.$ on $\left.\mathrm{P}_{1}{ }^{\wedge} \mathrm{P}_{2}\right), 58.51\left(\mathrm{OCH}_{3}\right), 106.86\left(\mathrm{C}_{\beta}\right), 123.05\left(\mathrm{C}_{\mathrm{d}}\right), 123.12\left(\mathrm{C}_{\mathrm{e}}\right), 125.33\left(\mathrm{C}_{\mathrm{g}}\right)$, $126.47\left(\mathrm{C}_{\mathrm{b}}\right), 127.73\left(\mathrm{C}_{\mathrm{i}}+\mathrm{C}_{\mathrm{m}}\right), 128.36\left(\mathrm{C}_{\mathrm{l}}+\mathrm{C}_{\mathrm{j}}\right), 131.59\left(\mathrm{C}_{\mathrm{k}}\right), 137.58\left(\mathrm{C}_{\delta}\right), 137.83\left(\mathrm{C}_{\mathrm{f}}\right), 138.79$ $\left(C_{c}\right), 154.00\left(C_{a}\right), 154.52\left(C_{h}\right), 155.50\left(C_{I I}\right), 156.83\left(C_{I}\right), 198.31\left(C_{\gamma}\right), 254.61\left(C_{\alpha}\right), 128.24,129.20$, $129.86,131.59,133.49,136.16$ (12C of Ph rings on $\left.P_{1}\right), 128.64,128.70,129.03,129.68132 .37$, 132.43, 134.88, 137.55, (12C of Ph rings on $\left.\mathrm{P}_{2}\right) .{ }^{31} \mathrm{P}\left\{{ }^{1} \mathrm{H}\right\} \mathrm{NMR}\left(243 \mathrm{MHz}, \mathrm{CD}_{2} \mathrm{Cl}_{2}\right): \delta 67.50(\mathrm{~d}$, $\left.J_{\mathrm{P} 1 \mathrm{P} 2}=20.3 \mathrm{~Hz}, \mathrm{P}_{1}\right), 74.16\left(\mathrm{~d}, J_{\mathrm{P} 2 \mathrm{P} 1}=20.3 \mathrm{~Hz}, \mathrm{P}_{2}\right)$. ESI-MS $m / z$ calcd. for $\mathrm{C}_{46} \mathrm{H}_{41} \mathrm{~N}_{2} \mathrm{O}_{2} \mathrm{P}_{2} \mathrm{Ru}$ $\left([7]^{+}\right): 816.9$, Found: 817.1 .

\subsubsection{Synthesis of $[8](\mathrm{OTf})$}

The procedure for the synthesis of [8](OTf) was the same as that for [6](OTf), except that cis-[Ru(bpy)(dppe) $\left.\mathrm{Cl}_{2}\right]$ was used instead of cis-[Ru(bpy)(dppm) $\left.\mathrm{Cl}_{2}\right]$. During refluxing, the metal precursor gradually dissolved and the color of the reaction mixture changed from deep yellow to pale yellow. The crude product, [8](OTf), was eluted as a yellow band using a $\mathrm{CH}_{2} \mathrm{Cl}_{2} /\left(\mathrm{CH}_{3}\right)_{2} \mathrm{CO} 5: 5(\mathrm{v} / \mathrm{v})$ mixture as eluent on a basic alumina column. Analytically pure yellow crystals of [8](OTf) were obtained by the recrystallization of the collected band via layering of $n$-hexane onto a $\mathrm{CH}_{2} \mathrm{Cl}_{2}$ solution of the complex.

[8](OTf). Yield: 40\%. Anal. Calcd for $\mathrm{C}_{38} \mathrm{H}_{32} \mathrm{ClF}_{3} \mathrm{~N}_{2} \mathrm{O}_{4} \mathrm{P}_{2} \mathrm{SRu}$ : C, 52.57; H, 3.71; N, 3.23 . Found: C, 52.57; H, 3.72; N, 3.24. ${ }^{1} \mathrm{H}\left\{{ }^{31} \mathrm{P}\right\}$ NMR (600 MHz, MeOD): $\delta$ 2.90-2.95, 3.07-3.11, 3.33-3.36 (m, 4H, $\left(\mathrm{CH}_{2}\right)_{2}$ on $\left.\mathrm{P}_{1}{ }^{\wedge} \mathrm{P}_{2}\right), 6.86-6.98\left(\mathrm{~m}, 1 \mathrm{H}, \mathrm{H}_{\mathrm{b}}\right), 7.59-7.60\left(\mathrm{~m}, 1 \mathrm{H}, \mathrm{H}_{\mathrm{a}}\right), 7.80-7.82$ $\left(\mathrm{m}, 1 \mathrm{H}, \mathrm{H}_{\mathrm{g}}\right), 7.86-7.89\left(\mathrm{~m}, 1 \mathrm{H}, \mathrm{H}_{\mathrm{c}}\right), 8.25-8.28\left(\mathrm{~m}, 2 \mathrm{H}, \mathrm{H}_{\mathrm{d}}+\mathrm{H}_{\mathrm{f}}\right), 8.48-8.49\left(\mathrm{~m}, 1 \mathrm{H}, \mathrm{H}_{\mathrm{e}}\right)$, 9.30-9.31 (m, 1H, $\left.\mathrm{H}_{\mathrm{h}}\right), 7.46-7.47,7.48-7.50,7.55-7.57,8.09-8.10,8.28-8.30(\mathrm{~m}, 10 \mathrm{H}$, protons of $\mathrm{Ph}$ rings on $\left.\mathrm{P}_{2}\right), 6.64-6.65,6.92-6.95,7.14-7.16,7.51-7.55,7.68-7.69(\mathrm{~m}, 10 \mathrm{H}$, protons of $\mathrm{Ph}$ rings on $\left.\mathrm{P}_{1}\right) .{ }^{13} \mathrm{C}\left\{{ }^{1} \mathrm{H}\right\} \mathrm{NMR}(151 \mathrm{MHz}, \mathrm{MeOD}): \delta 24.80,27.35\left(\left(\mathrm{CH}_{2}\right)_{2}\right.$ on $\left.\mathrm{P}_{1}{ }^{\wedge} \mathrm{P}_{2}\right), 125.35\left(\mathrm{C}_{\mathrm{d}}\right)$, $125.70\left(C_{e}\right), 127.26\left(C_{b}\right), 129.01\left(C_{g}\right), 141.05\left(C_{f}\right), 141.14\left(C_{c}\right), 153.50\left(C_{a}\right), 156.57\left(C_{I I}\right), 154.90$ $\left(C_{h}\right), 157.21\left(C_{I}\right), 202.14(C O), 130.05,130.60,132.15,132.20,132.21,133.02,134.16,136.12$ $\left(12 \mathrm{C}\right.$ of $\mathrm{Ph}$ rings on $\left.\mathrm{P}_{2}\right) 130.00,130.10,130.54,130.93,131.74,133.09$ (12C of Ph rings on $\mathrm{P}_{1}$ ). ${ }^{31} \mathrm{P}\left\{{ }^{1} \mathrm{H}\right\}$ NMR $(243 \mathrm{MHz}, \mathrm{MeOD}): \delta 51.09\left(\mathrm{~d}, J_{\mathrm{P} 2 \mathrm{P} 1}=13.29 \mathrm{~Hz}, \mathrm{P}_{2}\right), 62.71\left(\mathrm{~d}, J_{\mathrm{P} 1 \mathrm{P} 2}=13.29 \mathrm{~Hz}\right.$, $\left.\mathrm{P}_{1}\right)$. IR( $\left.\mathrm{KBr}, \mathrm{cm}^{-1}\right): v_{\mathrm{CO}}=1983$. ESI-MS $m / z$ calcd. for $\mathrm{C}_{37} \mathrm{H}_{32} \mathrm{ClN}_{2} \mathrm{OP}_{2} \mathrm{Ru}\left([8]^{+}\right): 719.1$, Found: 719.0 .

\subsection{X-ray Crystallographic Data}

CCDC 2144812-2144816 contain the supplementary crystallographic data for this paper. These data can be obtained free of charge via http:/ / www.ccdc.cam.ac.uk/conts / 
retrieving.html, accessed on 3 February 2022 (or from the CCDC, 12 Union Road, Cambridge, CB2 1EZ, U.K.; Fax: +44-1223-336033; E-mail: deposit@ccdc.cam.ac.uk).

\subsection{Cytotoxicity Studies}

The cytotoxicity of [4](OTf), [5](OTf), [7](OTf), [9](OTf) and cisplatin (cis-[Pt( $\left.\left.\mathrm{NH}_{3}\right)_{2} \mathrm{Cl}_{2}\right]$ ) against HeLa cancer cells was evaluated using the CCK8 assay [66]. Briefly, HeLa cells were seeded at 4000 cells per well in a 96-well culture microplate using $100 \mu \mathrm{L} \mathrm{10 \%} \mathrm{FBS} \mathrm{and} \mathrm{1 \%}$ PS DMEM as culture solution and incubated for $12 \mathrm{~h}$ at standard incubation conditions for mammalian cells ( $37^{\circ} \mathrm{C}, 5 \% \mathrm{CO}_{2}, 95 \%$ air). Stock solutions of [4](OTf), [5](OTf), [7](OTf) and [9](OTf) $(100 \mu \mathrm{M})$ were prepared using DMSO as solvent, whereas that of cisplatin $(100 \mu \mathrm{M})$ was prepared using $0.9 \%(w / v)$ saline solution as solvent. A series of concentrations for [4](OTf) and [7](OTf) (7.8 nM-10 $\mu \mathrm{M})$, [5](OTf) and [9](OTf) (0.38 nM-25 $\mu \mathrm{M})$, and cisplatin $(9.5 \mathrm{nM}-250 \mu \mathrm{M})$ were prepared in solutions with 10\% FBS and 1\% PS DMEM; $100 \mu \mathrm{L}$ of each solution was added to each well and the microplate was incubated for $24 \mathrm{~h}$ at standard incubation conditions for mammalian cells $\left(37^{\circ} \mathrm{C}, 5 \% \mathrm{CO}_{2}, 95 \%\right.$ air). For [4](OTf), [5](OTf), [7](OTf) and [9](OTf), the highest concentration of the complex-treated cell culture medium constitutes $0.5 \%$ DMSO. For the corresponding control experiments, $0.5 \%$ DMSO were used. Afterwards, the complex-containing culture medium was replaced by CCK8 reagent in 10\% FBS and 1\% PS DMEM $(1: 10 \mathrm{v} / \mathrm{v})$ and the microplate was incubated for $2 \mathrm{~h}$. Upon incubation, the microplate was shaken at room temperature for $10 \mathrm{~s}$ and absorbance measurement was carried out at $450 \mathrm{~nm}$ using a microplate reader. The cytotoxicity of each complex, expressed as $\mathrm{IC}_{50}$, was determined by the surviving cells curve after exposure to the complexes for $24 \mathrm{~h}$. Each experiment was repeated three times to obtain the mean values.

\section{Conclusions}

Mononuclear cis-[Ru( $\left.\left.\kappa^{2}-\mathrm{dppm}\right)(\mathrm{bpy}) \mathrm{Cl}_{2}\right](\mathbf{1})$, cis-[Ru( $\left.\left.\kappa^{2}-\mathrm{dppe}\right)(\mathrm{bpy}) \mathrm{Cl}_{2}\right](\mathbf{2})$, and dinuclear $\left[\mathrm{Ru}_{2}(\mathrm{bpy})_{2}(\mu \text {-dpam })_{2}(\mu-\mathrm{Cl})_{2}\right](\mathrm{Cl})_{2}\left([3](\mathrm{Cl})_{2}\right)$, were prepared from the reactions between $\operatorname{cis}(\mathrm{Cl})$, cis(S)-[Ru(bpy)(dmso-S $\left.)_{2} \mathrm{Cl}_{2}\right]$ and diphosphine/diarsine ligands dppm, dppe, and dpam, respectively. The reaction between 2 and $\mathrm{HC} \equiv \mathrm{C}(\mathrm{C}=\mathrm{O}) \mathrm{Ph}$ in $\mathrm{MeOH}$ only led to the formation of methoxy-substituted ruthenafuran $\left[\mathrm{Ru}(\mathrm{bpy})\left(\mathrm{k}^{2}-\mathrm{dppe}\right)\left(\mathrm{C}^{\wedge} \mathrm{O}\right)\right]^{+}\left([7]^{+}\right)$, but reacting 1 with $\mathrm{HC} \equiv \mathrm{C}(\mathrm{C}=\mathrm{O}) \mathrm{Ph}$ under identical reaction conditions gave a mixture of methoxy-substituted ruthenafuran $\left[\mathrm{Ru}(\mathrm{bpy})\left(\mathrm{k}^{2}-\mathrm{dppm}\right)\left(\mathrm{C}^{\wedge} \mathrm{O}\right)\right]^{+}\left([4]^{+}\right)$and phosphoniumring-fused bicyclic ruthenafuran $\left[\mathrm{Ru}(\mathrm{bpy})\left(\mathrm{P}^{\wedge} \mathrm{C}^{\wedge} \mathrm{O}\right) \mathrm{Cl}\right]^{+}\left([5]^{+}\right)$. These findings revealed that (1) the functionalized alkyne $\mathrm{HC} \equiv \mathrm{C}(\mathrm{C}=\mathrm{O}) \mathrm{Ph}$ was activated by $\mathbf{1}$ and 2 via a vinylideneinvolving pathway, and (2) bidentate ligands with small bite-angles, such as dppm, could induce new reactivity due to a ring strain. Both methoxy-substituted ruthenafuran and phosphonium-ring-fused bicyclic ruthenafuran were found to exhibit moderate-to-strong cytotoxicity against cervical carcinoma (HeLa) cancer cell line. Encouragingly, they were found to be one order of magnitude more cytotoxic than the classic metal-based anticancer agent cisplatin.

Supplementary Materials: The following are available online. Figures S1-S69: NMR spectra of all complexes reported in this work; Figures S70-S85: Experimental and simulated mass spectra of all complexes reported in this work.

Author Contributions: Conceptualization, C.-F.Y., S.-H.T., Z.Y. and C.-Y.W.; methodology, C.-F.Y., S.-H.T., Z.Y. and C.-Y.W.; investigation, C.-F.Y., S.-H.T., Z.Y., T.-Y.L., K.-K.L., Y.-M.C., H.-L.S., K.-W.I., K.-T.T., S.-M.Y. and M.-K.T.; data curation, C.-F.Y., S.-H.T. and Z.Y.; writing-original draft preparation, C.-F.Y. and S.-H.T.; writing-review and editing, C.-F.Y. and C.-Y.W.; supervision, C.-Y.W.; project administration, C.-Y.W.; funding acquisition, C.-Y.W. All authors have read and agreed to the published version of the manuscript.

Funding: The work described in this paper was supported by the Research Grants Council of Hong Kong SAR (CityU 11305920 and T42-103/16-N) and City University of Hong Kong (7005604).

Institutional Review Board Statement: Not applicable. 
Informed Consent Statement: Not applicable.

Data Availability Statement: Not applicable.

Conflicts of Interest: The authors declare no conflict of interest.

\section{References}

1. Schore, N.E. Transition metal-mediated cycloaddition reactions of alkynes in organic synthesis. Chem. Rev. 1988, 88, 1081-1119. [CrossRef]

2. Adams, R.D. The insertion of alkynes into metal-metal bonds and organic chemistry of the dimetallated olefin complexes. Chem. Soc. Rev. 1994, 23, 335-339. [CrossRef]

3. McDonald, F.E. Alkynol endo-Cycloisomerizations and Conceptually Related Transformations. Chem. Eur. J. 1999, 5, 3103-3106. [CrossRef]

4. Bubnov, Y.N.; Klimkina, E.V. Synthesis of some alkaloids using the allyl derivatives of boron (review). Chem. Heterocycl. Compd. 1999, 35, 888-899. [CrossRef]

5. Nakamura, I.; Yamamoto, Y. Transition-Metal-Catalyzed Reactions in Heterocyclic Synthesis. Chem. Rev. 2004, 104, 2127-2198. [CrossRef]

6. Zeni, G.; Larock, R.C. Synthesis of heterocycles via palladium pi-olefin and pi-alkyne chemistry. Chem. Rev. 2004, 104, 2285-2310. [CrossRef]

7. Mori, M. Activation of nitrogen for organic synthesis. J. Organomet. Chem. 2004, 689, 4210-4227. [CrossRef]

8. Nevado, C.; Echavarren, A.M. Transition Metal-Catalyzed Hydroarylation of Alkynes. Synthesis 2005, 2, 167-182. [CrossRef]

9. Hashmi, A.S.K. Gold-Catalyzed Organic Reactions. Chem. Rev. 2007, 107, 3180-3211. [CrossRef]

10. Lazzaroni, R.; Settambolo, R.; Rocchiccioli, S.; Guazzelli, G. From chiral and prochiral N-allylpyrroles to stereodefined pyrrole fused architectures: A particular application of the rhodium-catalyzed hydroformylation. J. Organomet. Chem. 2007, 692, 1812-1816. [CrossRef]

11. Li, Z.; Brouwer, C.; He, C. Gold-Catalyzed Organic Transformations. Chem. Rev. 2008, 108, 3239-3265. [CrossRef] [PubMed]

12. Patil, N.T.; Yamamoto, Y. Coinage metal-assisted synthesis of heterocycles. Chem. Rev. 2008, 108, 3395-3442. [CrossRef] [PubMed]

13. Kirsh, S.F. Construction of Heterocycles by the Strategic Use of Alkyne $\pi$-Activation in Catalyzed Cascade Reactions. Synthesis 2008, 20, 3183-3204. [CrossRef]

14. Cadierno, V.; Gimeno, J. Allenylidene and Higher Cumulenylidene Complexes. Chem. Rev. 2009, 109, 3512-3560. [CrossRef]

15. Kitamura, T. Transition-Metal-Catalyzed Hydroarylation Reactions of Alkynes Through Direct Functionalization of C-H Bonds: A Convenient Tool for Organic Synthesis. Eur. J. Org. Chem. 2009, 8, 1111-1125. [CrossRef]

16. Wahba, A.E.; Hamann, M.T. New One-Pot Methodologies for the Modification or Synthesis of Alkaloid Scaffolds. Mar. Drugs 2010, 8, 2395-2416. [CrossRef]

17. Patil, N.T.; Kavthe, R.D.; Yamamoto, Y. Metal-Catalyzed Intramolecular Heteroatom (X) $\rightarrow$ Carbon (C) Functional Group Migration Reactions Involving Additions of X-Y Bonds Across Alkynes. Adv. Heterocycl. Chem. 2010, 101, 75-95. [CrossRef]

18. Shao, Z.; Peng, F. Metal-Mediated Oxidative Cross-Coupling of Terminal Alkynes: A Promising Strategy for Alkyne Synthesis. Angew. Chem. Int. Ed. 2010, 49, 9566-9568. [CrossRef]

19. Müller, T.J.J. Palladium-Copper Catalyzed Alkyne Activation as an Entry to Multicomponent Syntheses of Heterocycles. In Synthesis of Heterocycles via Multicomponent Reactions II. Topics in Heterocyclic Chemistry; Orru, R., Ruijter, E., Eds.; Springer: Berlin/Heidelberg, Germany, 2010; Volume 25, pp. 25-94.

20. Vaquero, J.J.; Alvarez-Builla, J. Heterocycles Containing a Ring-Junction Nitrogen. In Modern Heterocyclic Chemistry; Alvarez-Builla, J., Vaquero, J.J., Barluenga, J., Eds.; Wiley-VCH: Weinheim, Germany, 2011; pp. 1989-2070.

21. Gomez-Suarez, A.; Nolan, S.P. Dinuclear Gold Catalysis: Are Two Gold Centers Better than One? Angew. Chem. Int. Ed. 2012, 51, 8156-8159. [CrossRef]

22. Marinetti, A.; Jullien, H.; Voituriez, A. Enantioselective, transition metal catalyzed cycloisomerizations. Chem. Soc. Rev. 2012, 41, 4884-4908. [CrossRef]

23. Watson, I.D.G.; Toste, F.D. Catalytic enantioselective carbon-carbon bond formation using cycloisomerization reactions. Chem. Sci. 2012, 3, 2899-2919. [CrossRef]

24. Zhang, D.-H.; Zhang, Z.; Shi, M. ChemInform Abstract: Transition Metal-Catalyzed Carbocyclization of Nitrogen and OxygenTethered 1,n-Enynes and Diynes: Synthesis of Five or Six-Membered Heterocyclic Compounds. Chem. Commun. 2012, 48, 10271-10279. [CrossRef] [PubMed]

25. Gulevich, A.V.; Dudnik, A.S.; Chernyak, N.; Gevorgyan, V. Transition metal-mediated synthesis of monocyclic aromatic heterocycles. Chem. Rev. 2013, 113, 3084-3213. [CrossRef] [PubMed]

26. Shiroodi, R.K.; Gevorgyan, V. Metal-catalyzed double migratory cascade reactions of propargylic esters and phosphates. Chem. Soc. Rev. 2013, 42, 4991-5001. [CrossRef]

27. Chinchilla, R.; Najera, C. Chemicals from Alkynes with Palladium Catalysts. Chem. Rev. 2014, 114, 1783-1826. [CrossRef]

28. Fürstner, A. From Understanding to Prediction: Gold- and Platinum-Based $\pi$-Acid Catalysis for Target Oriented Synthesis. Acc. Chem. Res. 2014, 47, 925-938. [CrossRef] 
29. Fensterbank, L.; Malacria, M. Molecular Complexity from Polyunsaturated Substrates: The Gold Catalysis Approach. Acc. Chem. Res. 2014, 47, 953-965. [CrossRef]

30. Dixneuf, P.H. Early Steps of Homogeneous Catalysis in Rennes: Carbon Dioxide Incorporation, Alkyne Activation and Ruthenium Catalysis. Catal. Lett. 2015, 145, 360-372. [CrossRef]

31. Chung, L.-H.; Wong, C.-Y. Ruthenium-Induced Alkyne Cycloisomerization: Construction of Metalated Heterocycles, Revelation of Unconventional Reaction Pathways, and Exploration of Functional Applications. Chem. Eur. J. 2019, 25, 2889-2897. [CrossRef]

32. Chung, L.-H.; Yeung, C.-F.; Wong, C.-Y. Ruthenium-Induced Cyclization of Heteroatom-Functionalized Alkynes: Progress, Challenges and Perspectives. Chem. Eur. J. 2020, 26, 6102-6112. [CrossRef]

33. Wong, C.-Y.; Man, W.-L.; Wang, C.; Kwong, H.-L.; Wong, W.-Y.; Lau, T.-C. Proton-Bridged Dinuclear (salen)Ru Carbene Complexes: Synthesis, Structure, and Reactivity of $\left\{\left[(\text { salchda }) \mathrm{Ru}=\mathrm{C}(\mathrm{OR})\left(\mathrm{CH}=\mathrm{CPh}_{2}\right)\right]_{2} \cdot \mathrm{H}\right\}^{+}$. Organometallics 2008, 27, 324-326. [CrossRef]

34. Wong, C.-Y.; Lai, L.-M.; Pat, P.-K. Ruthenium Acetylide Complexes Supported by Trithiacyclononane and Aromatic Diimine: Structural, Spectroscopic, and Theoretical Studies. Organometallics 2009, 28, 5656-5660. [CrossRef]

35. Wong, C.-Y.; Lai, L.-M.; Chan, S.-C.; Tai, L.-H. Photophysical and Theoretical Studies of Ruthenium(II)-Acetylide and -Cyanide Complexes with Aromatic Diimine and Trithiacyclononane. Organometallics 2010, 29, 6259-6266. [CrossRef]

36. Chung, L.-H.; Wong, C.-Y. Isolation of Ruthenium-Indolizine Complexes: Insight into the Metal-Induced Cycloisomerization of Propargylic Pyridines. Organometallics 2013, 32, 3583-3586. [CrossRef]

37. Chung, L.-H.; Yeung, C.-F.; Ma, D.-L.; Leung, C.-H.; Wong, C.-Y. Metal-Indolizine Zwitterion Complexes as a New Class of Organometallic Material: A Spectroscopic and Theoretical Investigation. Organometallics 2014, 33, 3443-3452. [CrossRef]

38. Tsui, W.-K.; Chung, L.-H.; Tsang, W.-H.; Yeung, C.-F.; Chiu, C.-H.; Lo, H.-S.; Wong, C.-Y. Synthesis, Spectroscopic and Theoretical Studies of Ruthenafuran and Osmafuran Prepared by Activation of Ynone in Alcohol. Organometallics 2015, 34, 1005-1012. [CrossRef]

39. Yeung, C.-F.; Chung, L.-H.; Lo, H.-S.; Chiu, C.-H.; Cai, J.; Wong, C.-Y. Isolation of Ruthenium-Indoline and -Indole Zwitterion Complexes: Insight into the Metal-Induced Cyclization of Aniline-Tethered Alkynes and Strategy to Lower the Activation Barrier of Metal-Vinylidene Formation. Organometallics 2015, 34, 1963-1968. [CrossRef]

40. Chung, L.-H.; Ng, S.-W.; Yeung, C.-F.; Shek, H.-L.; Tse, S.-Y.; Lo, H.-S.; Chan, S.-C.; Tse, M.-K.; Yiu, S.-M.; Wong, C.-Y. Rutheniumindolizinone complexes as a new class of metalated heterocyclic compounds: Insight into unconventional alkyne activation pathways, revelation of unexpected electronic properties and exploration of medicinal application. Dalton Trans. 2018, 47, 12838-12842. [CrossRef]

41. Chung, L.-H.; Yeung, C.-F.; Shek, H.-L.; Wong, C.-Y. Isolation of a C3-metalated indolizine complex and a phosphonium ring-fused bicyclic metallafuran from the osmium-induced transformation of pyridine-tethered alkynes. Faraday Discuss. 2019, 220, 196-207. [CrossRef]

42. Yeung, C.-F.; Chung, L.-H.; Ng, S.-W.; Shek, H.-L.; Tse, S.-Y.; Chan, S.-C.; Tse, M.-K.; Yiu, S.-M.; Wong, C.-Y. Phosphonium-RingFused Bicyclic Metallafuran Complexes of Ruthenium and Osmium. Chem. Eur. J. 2019, 25, 9159-9163. [CrossRef]

43. Chan, S.-C.; Yeung, C.-F.; Shek, H.-L.; Ng, S.-W.; Tse, S.-Y.; Tse, M.-K.; Yiu, S.-M.; Wong, C.-Y. Iron(II)-induced cycloisomerization of alkynes via "non-vinylidene" pathways for iron(II)-indolizine and -indolizinone complexes. Chem. Commun. 2020, 56, 12644-12647. [CrossRef] [PubMed]

44. Yeung, C.-F.; Chung, L.-H.; Tse, S.-Y.; Shek, H.-L.; Tse, M.-K.; Yiu, S.-M.; Wong, C.-Y. Conventional and unconventional alkyne activations by $\mathrm{Ru}$ and $\mathrm{Os}$ for unprecedented dimetalated quinolizinium complexes. Chem. Commun. 2020, 56, 8908-8911. [CrossRef] [PubMed]

45. Ng, S.-W.; Tse, S.-Y.; Yeung, C.-F.; Chung, L.-H.; Tse, M.-K.; Yiu, S.-M.; Wong, C.-Y. Ru(II)- and Os(II)-Induced Cycloisomerization of Phenol-Tethered Alkyne for Functional Chromene and Chromone Complexes. Organometallics 2020, 39, 1299-1309. [CrossRef]

46. Shek, H.-L.; Yeung, C.-F.; Chung, L.-H.; Wong, C.-Y. A focused review on the unconventional alkyne activations by ruthenium(II) and osmium(II) complexes supported by 1,2-bis(diphenylphosphino)methane (dppm). Polyhedron 2021, 197, 115023. [CrossRef]

47. Yeung, C.-F.; Shek, H.-L.; Yiu, S.-M.; Tse, M.-K.; Wong, C.-Y. Controlled Activation of Dipicolinyl-Substituted Propargylic Alcohol by $\mathrm{Ru}(\mathrm{II})$ and Os(II) for Unprecedented Indolizine-Fused Metallafuran Complexes. Organometallics 2021, 40, 2458-2466. [CrossRef]

48. Dierkes, P.; Van Leeuwen, P.W.N.M. The bite angle makes the difference: A practical ligand parameter for diphosphine ligands. J. Chem. Soc. Dalton Trans. 1999, 10, 1519-1529. [CrossRef]

49. Bianchini, C.; Innocenti, P.; Peruzzini, M.; Romerosa, A.; Zanobini, F. C-C Bond Formation between Vinylidene and Alkynyl Ligands at Ruthenium(II) Leading to either Enynyl or Dienynyl Complexes. Organometallics 1996, 15, 272-285. [CrossRef]

50. Bianchini, C.; Casares, J.A.; Peruzzini, M.; Romerosa, A.; Zanobini, F. The Mechanism of the Ru-Assisted C-C Bond Cleavage of Terminal Alkynes by Water. J. Am. Chem. Soc. 1996, 118, 4585-4595. [CrossRef]

51. Clarke, M.J. Ruthenium Metallopharmaceuticals. Coord. Chem. Rev. 2003, 236, 209-233. [CrossRef]

52. Brabec, V.; Novakova, O. DNA binding mode of ruthenium complexes and relationship to tumor cell toxicity. Drug Resist. Updates 2006, 9, 111-122. [CrossRef]

53. Kostova, I. Ruthenium complexes as anticancer agents. Curr. Med. Chem. 2006, 13, 1085-1107. [CrossRef] [PubMed]

54. Gasser, G.; Metzler-Nolte, N. The potential of organometallic complexes in medicinal chemistry. Curr. Opin. Chem. Biol. 2012, 16, 84-91. [CrossRef] [PubMed]

55. Gill, M.R.; Thomas, J.A. Ruthenium(II) polypyridyl complexes and DNA-from structural probes to cellular imaging and therapeutics. Chem. Soc. Rev. 2012, 41, 3179-3192. [CrossRef] [PubMed] 
56. Kandioller, W.; Balsano, E.; Meier, S.M.; Jungwirth, U.; Goschl, S.; Roller, A.; Jakupec, M.A.; Berger, W.; Keppler, B.K.; Hartinger, C.G. Organometallic anticancer complexes of lapachol: Metal centre-dependent formation of reactive oxygen species and correlation with cytotoxicity. Chem. Commun. 2013, 49, 3348-3350. [CrossRef] [PubMed]

57. Furrer, J.; Süss-Fink, G. Thiolato-bridged dinuclear arene ruthenium complexes and their potential as anticancer drugs. Coord. Chem. Rev. 2016, 309, 36-50. [CrossRef]

58. Kwong, W.-L.; Lam, K.-Y.; Lok, C.-N.; Lai, Y.-T.; Lee, P.-Y.; Che, C.-M. A Macrocyclic Ruthenium(III) Complex Inhibits Angiogenesis with Down-Regulation of Vascular Endothelial Growth Factor Receptor-2 and Suppresses Tumor Growth In Vivo. Angew. Chem. Int. Ed. 2016, 55, 13524-13528. [CrossRef] [PubMed]

59. Ma, L.; Ma, R.; Wang, Z.; Yiu, S.-M.; Zhu, G. Heterodinuclear Pt(IV)-Ru(II) anticancer prodrugs to combat both drug resistance and tumor metastasis. Chem. Commun. 2016, 52, 10735-10738. [CrossRef]

60. Rodrigues, F.P.; Carneiro, Z.A.; Mascharak, P.; Curti, C.; da Silva, R.S. Incorporation of a ruthenium nitrosyl complex into liposomes, the nitric oxide released from these liposomes and HepG2 cell death mechanism. Coord. Chem. Rev. 2016, 306, 701-707. [CrossRef]

61. Zeng, L.; Gupta, P.; Chen, Y.; Wang, E.; Ji, L.; Chao, H.; Chen, Z.-S. The development of anticancer ruthenium(II) complexes: From single molecule compounds to nanomaterials. Chem. Soc. Rev. 2017, 46, 5771-5804. [CrossRef]

62. Coverdale, J.P.C.; LaroiyaMcCarron, T.; Romero-Canelón, I. Designing Ruthenium Anticancer Drugs: What Have We Learnt from the Key Drug Candidates? Inorganics 2019, 7, 31. [CrossRef]

63. Lee, S.-Y.; Kim, C.-Y.; Nam, T.-G. Ruthenium Complexes as Anticancer Agents: A Brief History and Perspectives. Drug Des. Dev. Ther. 2020, 14, 5375-5392. [CrossRef] [PubMed]

64. Toyama, M.; Inoue, K.-I.; Iwamatsu, S.; Nagao, N. Syntheses and Crystal Structures of Mono(2,2'-bipyridine)dichlorobis-(dimethyl sulfoxide-S)ruthenium(II) Complexes, $\left[\mathrm{RuCl}_{2}(\mathrm{bpy})(\mathrm{dmso}-\mathrm{S})_{2}\right]$. Bull. Chem. Soc. Jpn. 2006, 79, 1525-1534. [CrossRef]

65. Schraml, J.; Čapka, M.; Blechta, V. ${ }^{31} \mathrm{P}$ and ${ }^{13} \mathrm{C}$ NMR spectra of cyclohexylphenylphosphines, tricyclohexylphosphine and triphenylphosphine. Magn. Reson. Chem. 1992, 30, 544-547. [CrossRef]

66. Chamchoy, K.; Pakotiprapha, D.; Pumirat, P.; Leartsakulpanich, U.; Boonyuen, U. Application of WST-8 based colorimetric $\mathrm{NAD}(\mathrm{P}) \mathrm{H}$ detection for quantitative dehydrogenase assays. BMC Biochem. 2019, 20, 4. [CrossRef] [PubMed] 